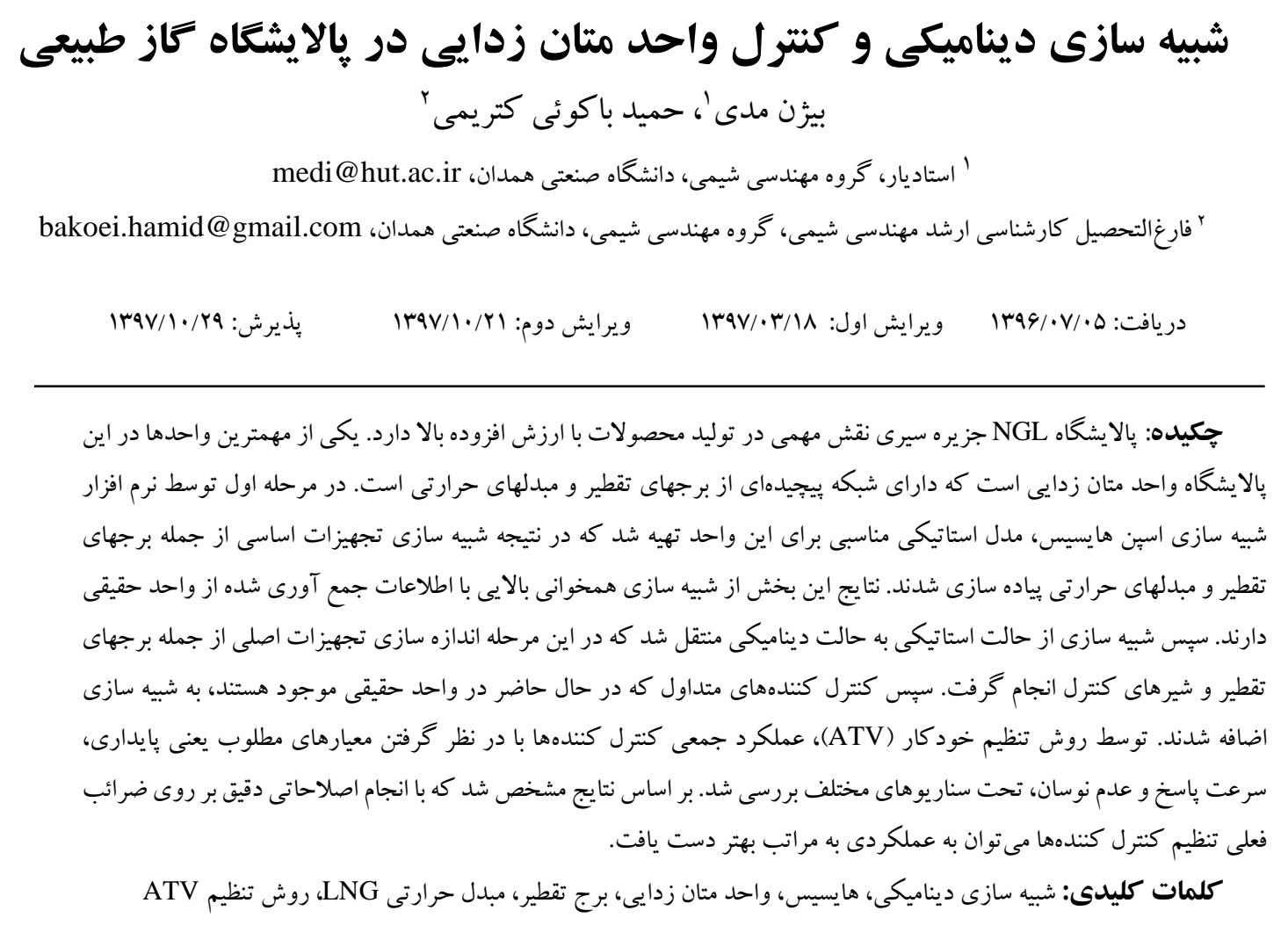

\title{
Dynamic Simulation and Control of the Demethanizer Unit in Natural Gas Refining Plant
}

\author{
Bijan Medi, Hamid Bakuei Katrimi
}

\begin{abstract}
The NGL refinery of the Sirri Island has a major role in the production of highvalue products. One of the most important refinery units is the demethanizer unit, comprising of a complex network of distillation towers and heat exchangers. In the first step, using the Aspen Hysys software, a proper steady state model was developed for this unit in which the simulation of the main equipment that is, distillation towers and heat exchangers were carried out. The steady state simulation results are in good agreement with the data gathered from the real plant. Then, the simulation was transferred from steady state to dynamic mode in which the main equipment such as distillation towers and control valves were sized. Here, the available controllers which are currently present in the real plant, were added to the simulation. Using the auto tuning variation (ATV) method and by considering the desired behavior namely, stability, fast response, and absence of oscillation, the overall performance of the controllers were examined under different scenarios. Based on the results, it was identified that with carefully tuning the controllers parameters, much better performance can be achieved.
\end{abstract}

Keywords: Dynamic simulation, Hysys, Demathanizer unit, Distillation tower, LNG heat exchanger, ATV method 
دوم بارس جنوبى توسط اتصال نرم افزارهاى اسين بِلاس ديناميك و متلب

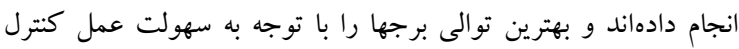

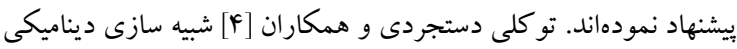

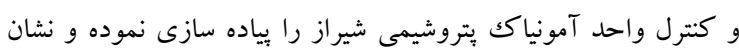

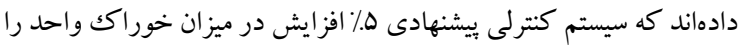
بخوبى مى تواند تحمل نمايد. بيمانى و همكاران [هـ شيبه سازى ديناميكي

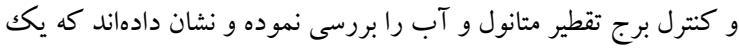

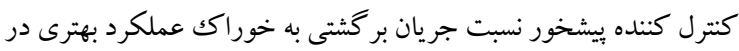

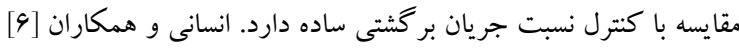

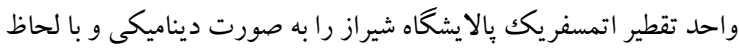

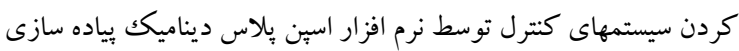

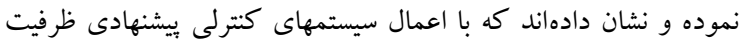

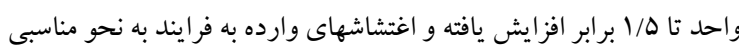

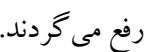

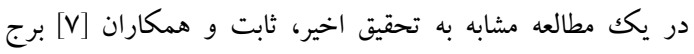

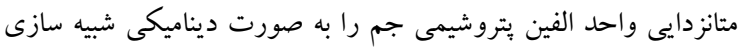

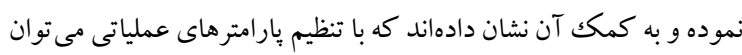
ظرفيت واحد و كيفيت محصول را افزايش داد، اخرجه در تحقيق آنها تجهيزات جانبى و حلقههاى كنترلى لحاظ نشدهاند.

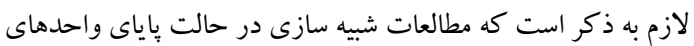

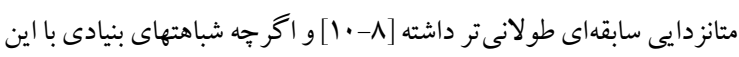
تحقيق دارند، اما در يياده سازى، شرايط ديناميكى مسائل به صورتى إنى

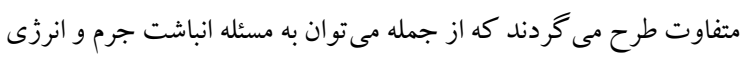
در تجهيزات و همجنين رابطه فشار -جريان اشاره كرد كه در مورد مسائل فئل

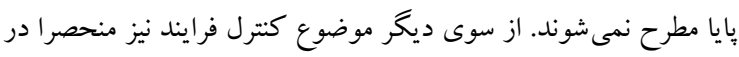
شبيه سازى ديناميكى مطرح مى خر دد.

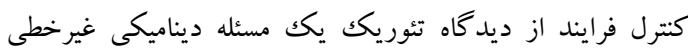

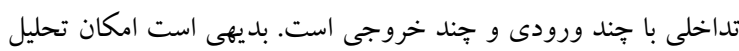

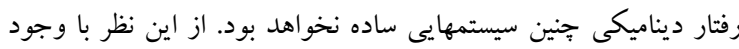

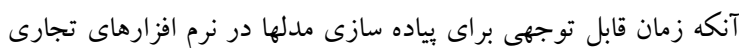

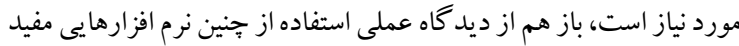

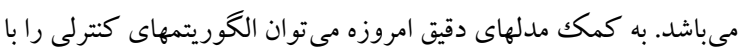
دقت بالا يياده سازى نمود. به علاوه با توجه به آنكه اجازه اعمال تغييرات آنسات

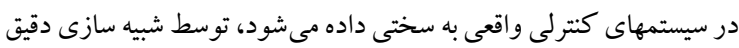

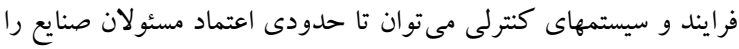
بدست آورد. در تحقيق حاضر كليه ادوات اصلى موجود در واحد متانزدايى به

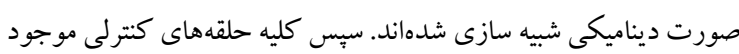
در فرايند با ضرايب عملياتى كه از منابع واحد بدست آمدانداند، به شبيه

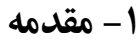

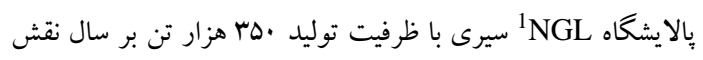

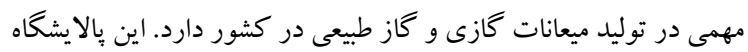

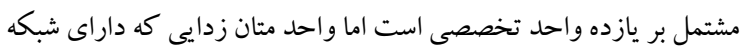

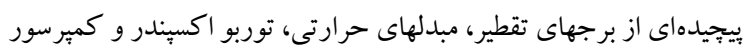

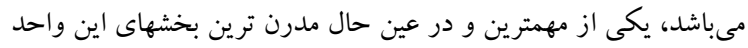

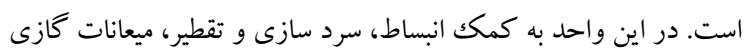

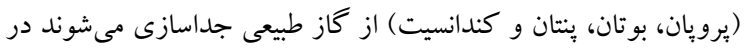

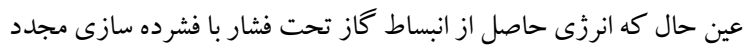
كاز محصول، بازيافت مى گردد.

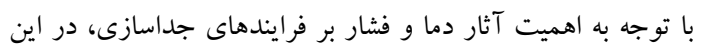
واحد، اين دو يارامتر مىبايست به طور دقيق تحت كنترل قرار داشته باشند.

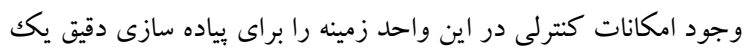

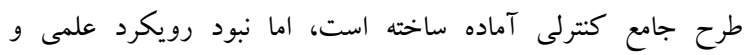
سيستماتيك، بهينه سازى حلقههاى كنترلى را محدود به آزمون و خطا

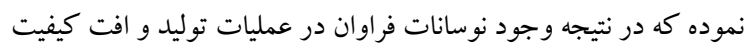

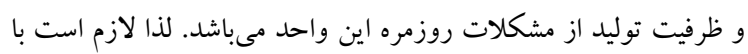

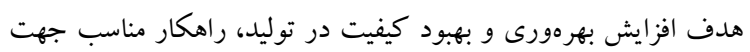
بهبود عمكلرد حلقههاى كنترلى ارائه گردد.

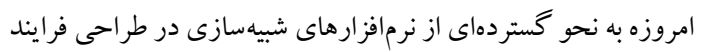

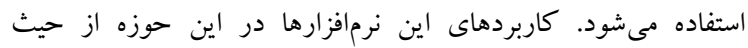

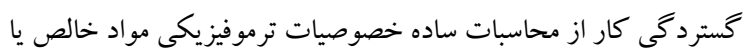
مخلوطها شروع شده و به طراحى كارخانجات كامل با بهينه سازى فرايند و طراحى سيستمهاى كنترل مىرسد كه در مورد اخير بايد اذعان نمود زمينه تخصصى شبيه سازى ديناميكى فرايند در ايران در مقايسه با ساير

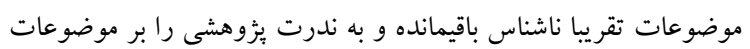

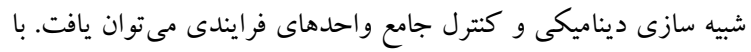

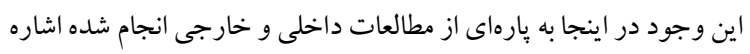

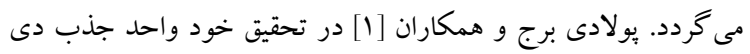

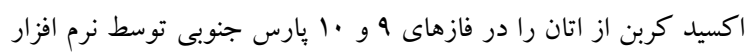

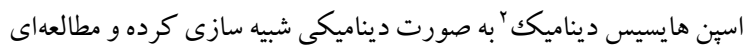

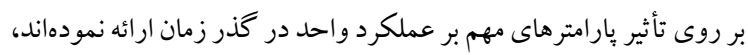

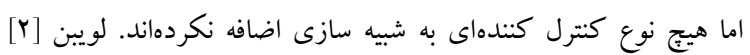

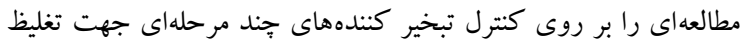

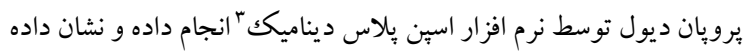

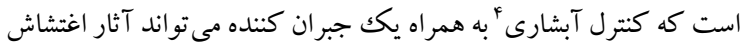
در شدت جريان خوراكك ورودى را به نحو بهترى در مقايسه با كنترل فيدبك ساده كاهش دهد. در تحقيقى ديخر خدادوست و همكاران [ـ

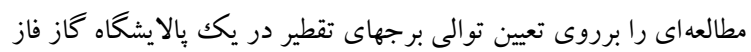


معادلات حاصل در همه موارد بهصورت تقريبى-عددى حل مىشود كه روش حل متداول، روش انتخر الخيرى اويلر ضمنى هاست.

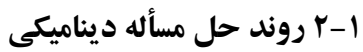

روند زير جهت حل يك مسأله ديناميكى در هايسيس بيشن دونهاد

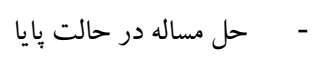

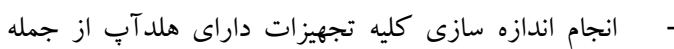

مخازن، برجها، مبدلهاى حرارتى و جداسازها

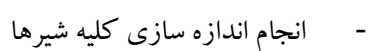

مشخص كردن استر اتزى كنترل و تر كيب بندى اجزاء كنترلى لى إنى

افزودن حلقههاى كنترلى مورد نياز در فلوشيت

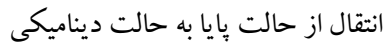

تعيين خصوصيات جريان-فشار جريانهاى ورودى-خروجى به به بـ

$$
\text { واحد }
$$

$$
\text { راه اندازى انتخر الخير }
$$

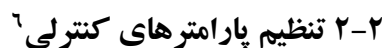

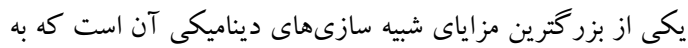

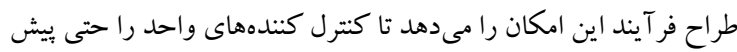

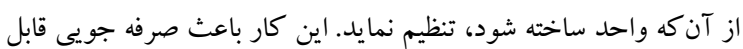

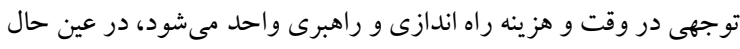

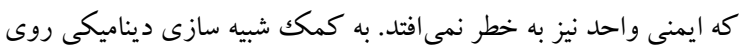
نرم افزار براحتى يكك سيستم كنترلى را در شرايط مشابه واقعيت مى توان

$$
\text { تنظيم كرد. }
$$

يكك كنترل كننده PID در فرم كلاسيك به صورت زير بيان مىشود

$$
\begin{aligned}
& \mathrm{u}=\mathrm{u}_{\mathrm{s}}+ \\
& \mathrm{K}_{\mathrm{p}}\left(\mathrm{e}(\mathrm{t})+\frac{1}{\mathrm{~T}_{\mathrm{i}}} \int \mathrm{e}(\mathrm{t}) \mathrm{dt}+\mathrm{T}_{\mathrm{d}} \frac{\mathrm{de}(\mathrm{t})}{\mathrm{dt}}\right)
\end{aligned}
$$

كه در اينجا (t) - آنطور كه در هايسيس ديناميك مورد استفاده قرار

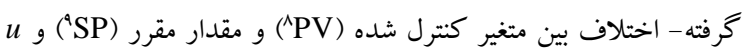

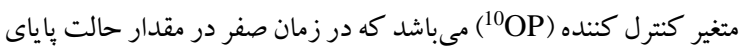
خود (uss) قرار دارد. ضرايب

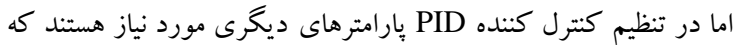

$$
\text { در ادامه تعريف مى تموند: }
$$

K

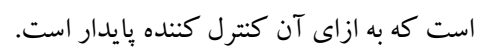

سازى اضافه شدهاند. بدين شكل يكك مدل ديناميكى جامع از واحد مذكور تهيه شده است. اما همانطور كه در بخش نتايج مشاهده خواهد شد و البته

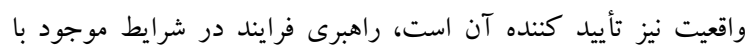
دشوارىهايى روبرو مىباشد كه از آن جمله مى توان به نوسان فراوان درد

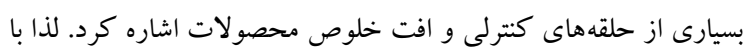
بررسى وضعيت كنترل كنندهها مشخص شد كه احتمالا تنظيم بِارامترهاى كنترلى مى تواند به رفع مشكلات موجود كمكك نمايد.

\section{ץ- شبيه سازى توسط نرم افزار اسين هايسيس}

ديناميكك

نرم افزار اسين هايسيس يكى از جامعترين نرم افزارهاى شبيه سازى در زمينه فرايندهاى نفت، گاز و يتروشيمى است. اين نرم افزار داراى كتابخانه

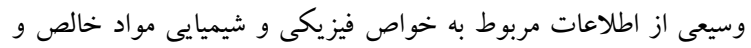

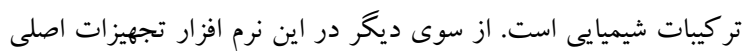

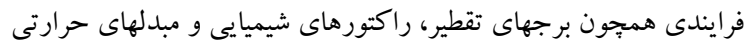

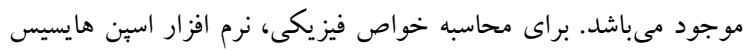

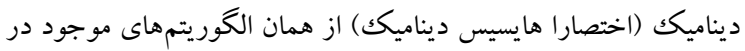

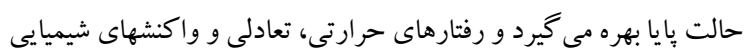

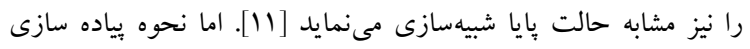

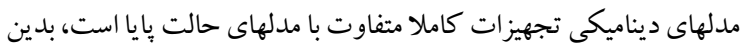

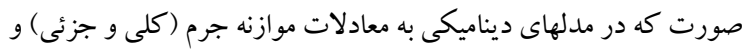

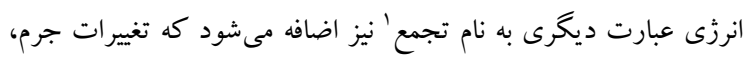

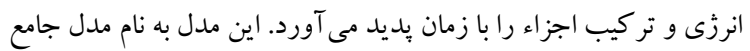

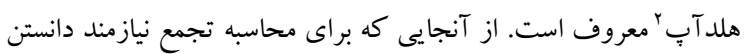

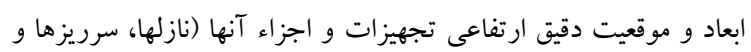

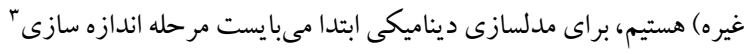

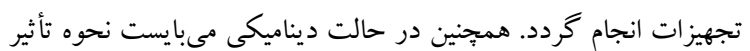

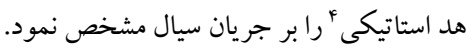
به طور كلى يكك مدل هلد آب براى سيستمى كه با محيط اطراف تبادل جرم يا انرزى دارد، به صورت زير نوشته مىشود:

$\frac{d y}{d t}=f_{y i}-f_{y o}+R_{y}$

كه در اين معادله y متغير فرايندى،

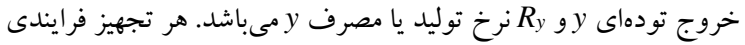

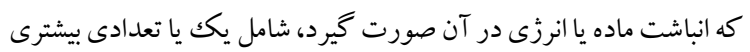

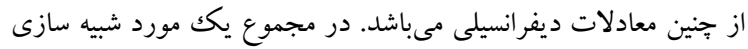

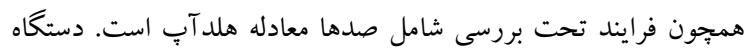

\footnotetext{
${ }^{1}$ Accumulation

${ }^{2}$ Hold up

${ }^{3}$ Sizing

${ }^{4}$ Static head

${ }^{5}$ Implicit Euler integration method
} 


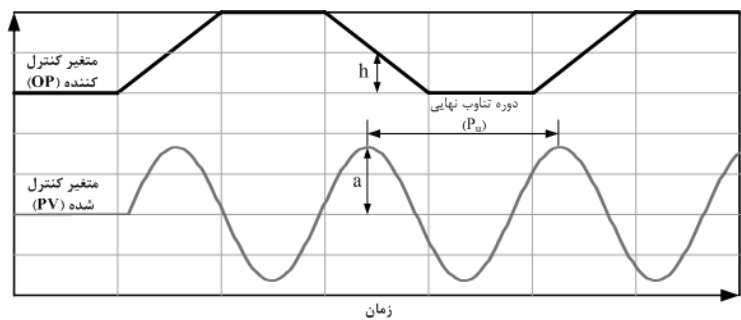

شكل ا: تعيين بارامترهاى سيستم جهت تنظيم ATV پارامترهاى كنترلى [11].

جدول ا: معادلات حاكم بر يارامترهاى كنترلى [11].

\begin{tabular}{|c|c|}
\hline معادله & بِارامترهاى كنترلى \\
\hline$K_{u}=\frac{4 h}{\pi a}$ & بهره نهايى \\
\hline$P_{u}=$ PV دوره تناوب موج & دوره تناوب نهايى \\
\hline$K_{p}=\frac{K_{u}}{1.2}, T_{i}=\frac{P_{u}}{2.2}$ & $\begin{array}{c}\text { كنترل تناسبى-انتخر الى } \\
\text { (PI) }\end{array}$ \\
\hline$K_{p}=\frac{K_{u}}{1.7}, T_{i}=\frac{P_{u}}{2}, T_{d}=\frac{P_{u}}{8}$ & $\begin{array}{l}\text { كنترل تناسبى انتر الى-مشتقى } \\
\text { (PID) }\end{array}$ \\
\hline
\end{tabular}

ب- روش تحقيق

روش تحقيق بر اساس شبهسازى با نرمافزار هايسيس ديناميكك و

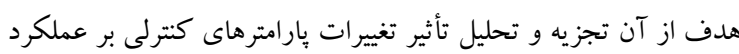

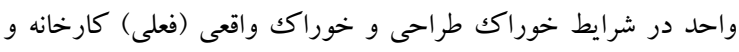

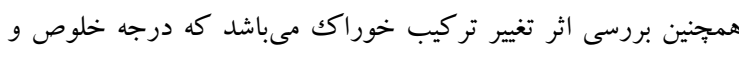

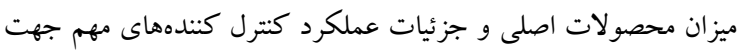

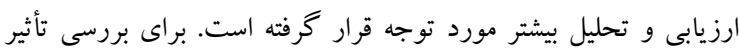

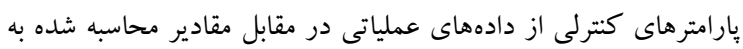

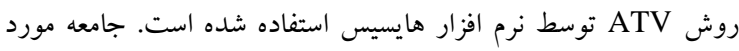

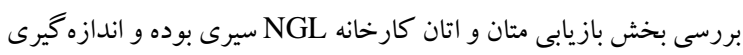

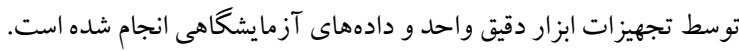

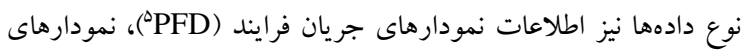

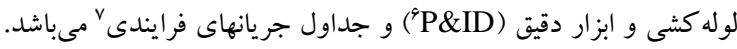

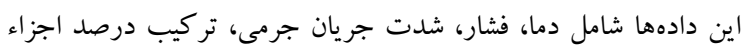

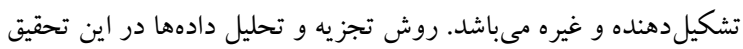
شبيهسازى استاتيكك و ديناميكى و ابزار تجزيه و تحليل دادهها نرمافزار

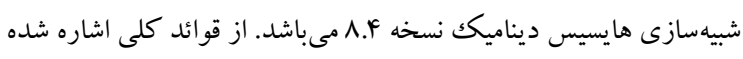

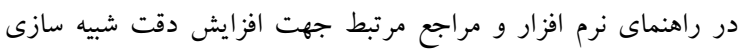

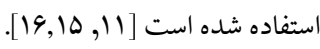

\section{1-اس شرح فرايند}

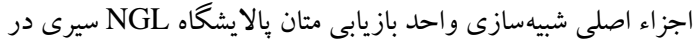
جدول r خلاصه شده و در شكل r نماى كلى واحد شبيه سازى شده دئس در

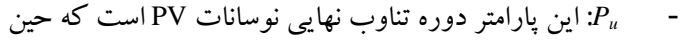

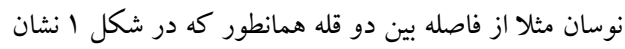

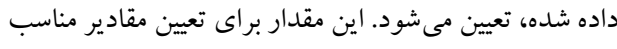

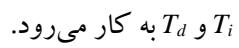

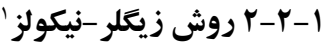

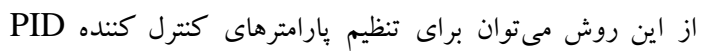
استفاده نمود. اين روش در اصل براى سيستمهاى الكترومكانيكى ايجاد

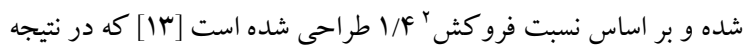

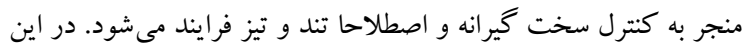

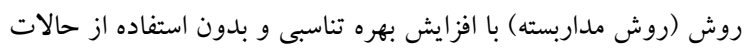

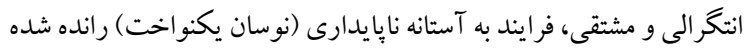

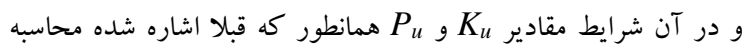

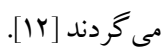

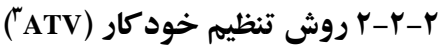

از روش ATV نيز مى توان براى سيستمهاى داراى زمار زمان مرده استفاده كرد. همان طور كه كفته شد، در روش زيخلر -نيكولز

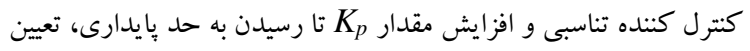

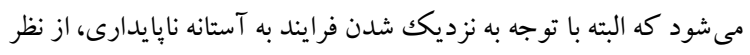
ايمنى نامطلوب است. اما در روش ATV،

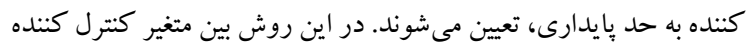

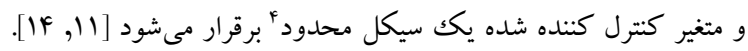

$$
\text { مراحل انجام اين روش به شرح زير است: }
$$

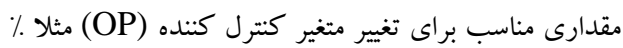

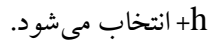

كنترل كننده را در حالت دستى قرار داده و OP را به به مقدار

انتخاب شده در مرحله قبل مىرسانند. صبر مىشود تا متغير كنترل شده (PV) شروع به تغيير كند.

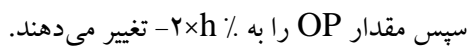

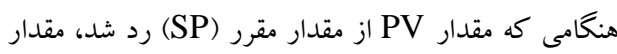

$$
\text { را به OP OP }
$$

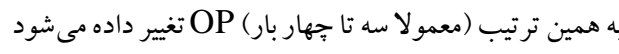

$$
\text { تا يكك سيكل محدود ايجاد شود. }
$$

$$
\text { دامنه موج PV را اندازه گر فته و 'a' مى نامند. }
$$

در نهايت يارامترهاى مى شوند. براى محاسبه ضرائب كنترلى از اين يارامترها

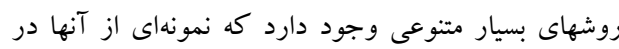

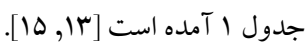

\footnotetext{
${ }^{5}$ Process flow diagram

${ }^{6}$ Piping \& instrumentation diagram

${ }^{7}$ Stream tables
}

\footnotetext{
${ }^{1}$ Ziegler-Nichols

${ }^{2}$ Decay ratio

${ }^{3}$ Auto tuning variation

${ }^{4}$ Limit cycle
} 
معادلات ترموديناميكى مىباشد. اين معادله در حالت كلى به فرم زير

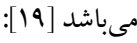

$$
\begin{gathered}
P=\frac{R T}{V-b}-\frac{a \alpha}{V[V+b]+b[V-b]} \\
a=0.45724 \frac{R^{2} T_{c}^{2}}{P_{c}} \\
b=0.07780 \frac{R T_{c}}{P_{c}} \\
\alpha a=\sum_{i} \sum_{j} x_{i} x_{j}\left(1-\delta_{i j}\right)\left(\alpha_{i} a_{i} \alpha_{j} a_{j}\right)^{1 / 2} \\
b=\sum_{i} x_{i} b_{i}
\end{gathered}
$$

\begin{tabular}{|c|c|c|}
\hline توضيحات & عنوان تجهيز فرايندى & علامت اختصارى \\
\hline 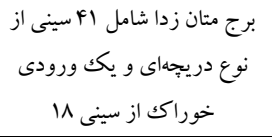 & $\begin{array}{l}\text { Demethanizer } \\
\text { Column }\end{array}$ & $13-\mathrm{C}-101$ \\
\hline 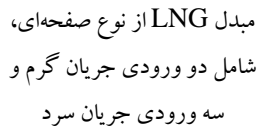 & Cold Exchanger & 13-E-101 \\
\hline مبدل از نوع يوسته-لوله با دو & Warm Gas Chiller & $13-E-102$ \\
\hline مبدل از نوع يوسته-لوله با دو & Cold Gas Chiller & 13-E-103 \\
\hline توربو اكسيندر & Turboexpander & $13-K-101$ \\
\hline كميرسور تكك مرحلهاى & Compressor & $13-K-102$ \\
\hline 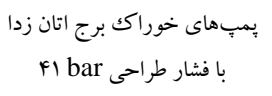 & $\begin{array}{c}\text { Deethanizer Feed } \\
\text { Pump }\end{array}$ & $\begin{array}{c}13-\mathrm{P}- \\
101 \mathrm{~A} / \mathrm{B}\end{array}$ \\
\hline جدا كننده دو فازى از نوع افقى با حجم ره متر مكعب & $\begin{array}{c}\text { Low Temperature } \\
\text { Separator }\end{array}$ & $13-\mathrm{D}-101$ \\
\hline 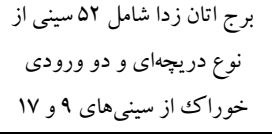 & Deethanizer Column & 14-C-101 \\
\hline ريبويلر از نوع يوسته-لوله با دو & Deethanizer Reboiler & 14-E-101 \\
\hline كندانسور از نوع يوسته-لوله با & $\begin{array}{l}\text { Deethanizer } \\
\text { Condenser }\end{array}$ & $14-E-102$ \\
\hline 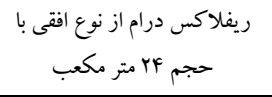 & $\begin{array}{l}\text { Deethanizer Reflux } \\
\text { Drum }\end{array}$ & 14-D-101 \\
\hline 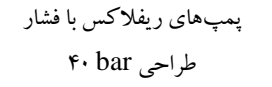 & $\begin{array}{l}\text { Deethanizer Reflux } \\
\text { Pump }\end{array}$ & $\begin{array}{c}\text { 14-P- } \\
101 \mathrm{~A} / \mathrm{B}\end{array}$ \\
\hline
\end{tabular}

جدول r: تجهيزات فرايندى واحد بازيابى متان.

حالت ديناميكى مشاهده مىشود. خوراكى كاز ورودى به واحد بازيابى متان (واحد سا) كه در واحدهاى بالا دستى شيرين سازى و نم زدايى شده در مرحله اول با عبور از تجهيز Cold Exchanger (13-E-101) تا دماى 9- درجه سانتيخراد سرد شده و سيس با عبور از مبدلهاى گرم و سرد -13 E-102\&103 كه بطور سرى قرار گرفتهاند، تا دماى •r- درجه سانتى گراد بوسيله سيال مبرد يرويان، سرد مى گردد. در مرحله بعد جريان دو فازى وارد جدا كننده دو فازى (13-D-101) مىشود و در آنجا دو فاز مايع و كاز از هم جدا مى شوند. فاز گاز از بالا به سمت توربواكسيندر (-13

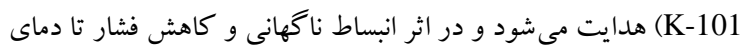
حدود 19- درجه سانتيكراد سرد شده و به عنوان خوراكك برج متان زدا وارد برج مىشود. فاز مايع نيز بعد از تبادل حرارت در (13-C-101) Cold Exchanger (14-C-101)

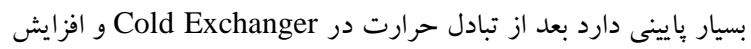
دما جهت افزايش فشار وارد كميرسور (13-K-102) مىشود. كاز خروجى از كميرسور (جريان R. Gas) با فشار حدود barg ب به به عنوان گاز مصرفى به بخش هاى مورد نياز ارسال مى گردد و تر كيبات سنگين از يايين برج توسط يميهاى خوراك (13-P-101) به برج اتان زدا ارسال

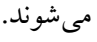

در برج اتان زدا محصولات بالا سرى وارد كندانسور جزئى (-E102-D- مىشود كه بعد از جداسازى فاز مايع و كاز در جدا كننده 101 فاز مايع به عنوان جر يان بر گشتى وارد برج مى شود و فاز گاز كه بيشتر شامل تركيبات متان و اتان مىباشد، بعد از تبادل حرارت در Cold سرد شده و به عنوان جريان ريفلاكس به سينى اول برج متان Exchanger زدا بر مى گردد. گرماى لازم در يايين برج توسط ريبويلر (14-E-101)

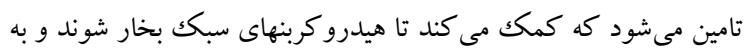
سمت بالاى برج حركت كرده و خارج شوند. مايعات باقيمانده (يرويان و اجزاء سنگين تر ) به برج يرويان زدا فرستاده مىشوند [IV].

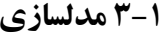

در شبيه سازى فر آيند از مدل هاى بسيار متنوعى استفاده مىشود كه از آن جمله مى توان به مدلهاى ترموديناميكى براى توصيف رفتار ماده خصوصا تعادلات فازى، مدلهاى انتقال جرم براى تحليل فرايندهاى جداسازى و مدلهاى سيالاتى براى محاسبات فشار-جريان استفاده كرد. على الخصوص به منظور شبيهسازى فرايندهاى جداسازى هيدروكربنى از جمله كاز طبيعى معادله ترموديناميكى ينگك-رابينسون (PR (1PR) بوفور مورد

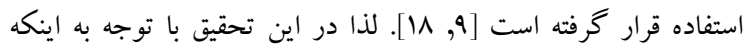
تر كيبات مزاحم همجِون گو گرد، آب و دى اكسيد كربن در مراحل قبلى

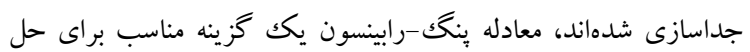




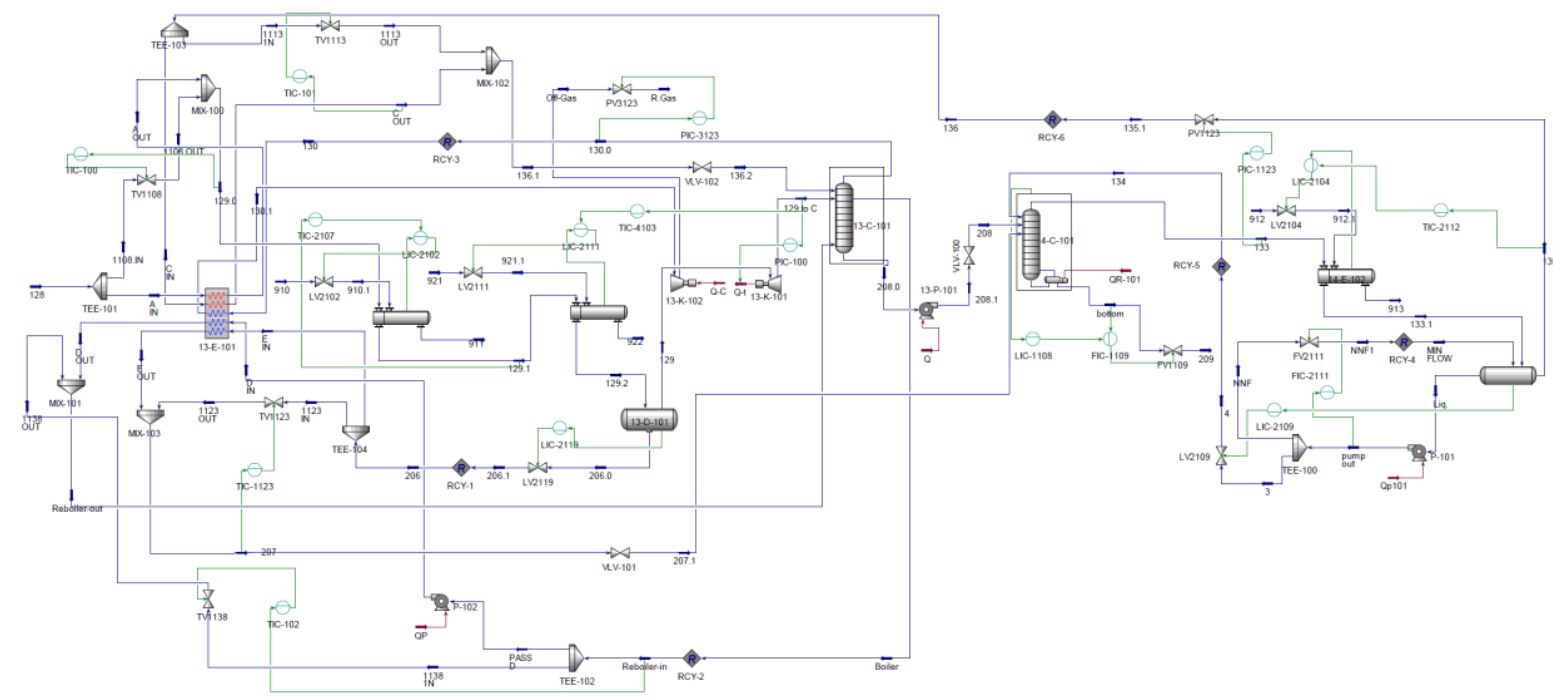

شكل ז: دياكرام شبيه سازى ديناميكى واحد متان زدايى بالايشگاه NGL سيرى.

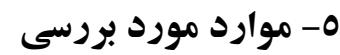

در كليه موارد مورد بررسى بارامترهاى اساسى واحد يعنى تركيب

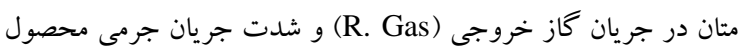

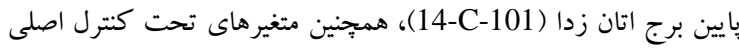

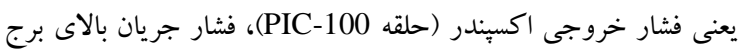

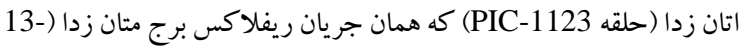

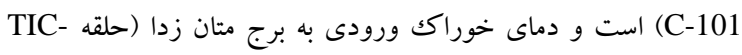
4103 بر برسى شدهاند. در مسئله اول شبيه سازى فرايند را از حالت بِيايا آغاز كرده و به حالت ديناميكى منتقل مى كنيم و رفتار ديناميكى فرايند را با توجه به ميزان

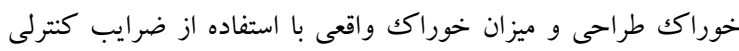
عملياتى و ضرايب حاصل از روش ATV بررسى مى برنماييم. در مورد

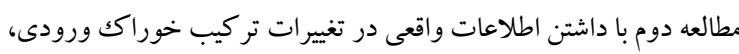

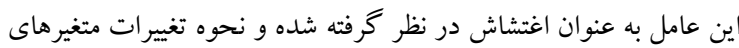

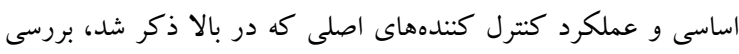
شدهاند. اين مطالعه نيز هم با استفاده از ضرايب كنترلى عملى كملياتى و و تنظيم ATV اما تنها در حالت خوراكى واقعى انجام شده است.

\section{1 - 1 نتايج}

در مورد اول بررسى يعنى شروع از حالت پايا، در ابتدا كتترل كنندها

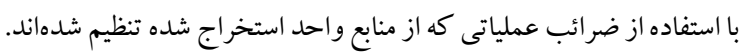

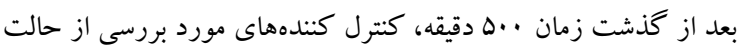

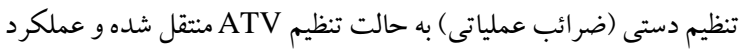

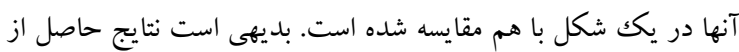
تنظيم ATV در شرايط خوراك طر احى و واقعى يكسان نخو اهند بود.

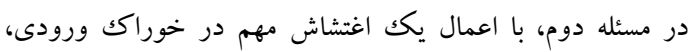
عملكرد كتترل كندهها در شرايطى كه فرايند از حالت بايا فاصله قابل درالي
كه در اين روابط T دما، P فشار و V حجم ويزه سيال مىباشد. ثوابت و و $a_{i}$ ضرايب برهمكنش دوتايى ( ${ }$ ) عموما با استفاده از آزمايش تعيين مى تردد [19]

از روش كليج [•r] به منظور تحليل طغيان بر روى سـينىهاى برجهاى

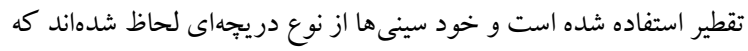

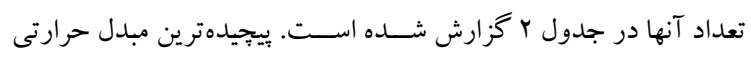

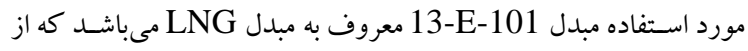

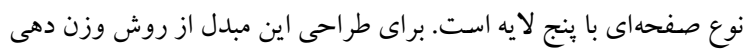

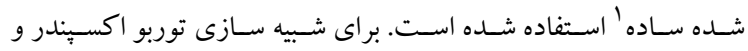
كمبرسور كارايى به صورت آدياباتيكك و به ميزان VD درصد لحاظ شـده

است.

\section{ع- روش جمع آورى دادههاى ميدانى}

در خصوص آناليز كاز خوراكى و به دليل راه داه اندازى نشدن دستكاه

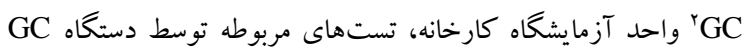
مدل Agilent ساخت كشور آمريكا در يُروهشكاه صنعت نفت انجام شده

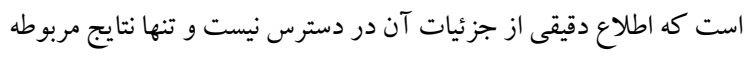

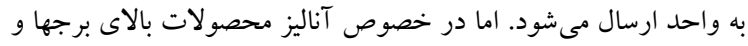

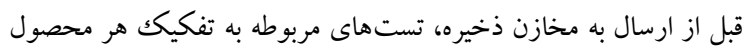

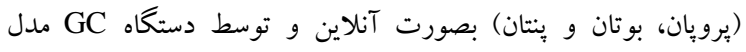
ساخت كثور زاين به فاصله زمانى هر هاب دقيقه انجام مىشود. همجنين مقادير ضرايب كنترلى نيز با مراجعه به اتاق كنترل

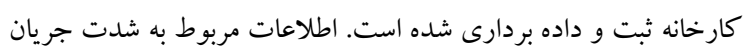

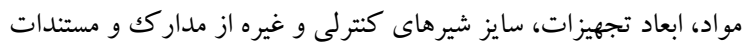
طراحى كارخانه حاصل شده است. 
طر احى يايا كه ....4 كيلو گرم بر ساعت مىباشد، اختلاف زيادى ندارد. همجنين مشاهده مىشود كه بعد از اعمال ضرائب تنظيم ATV ميزان نوسانات تا حدودى كاهش مى يابد.
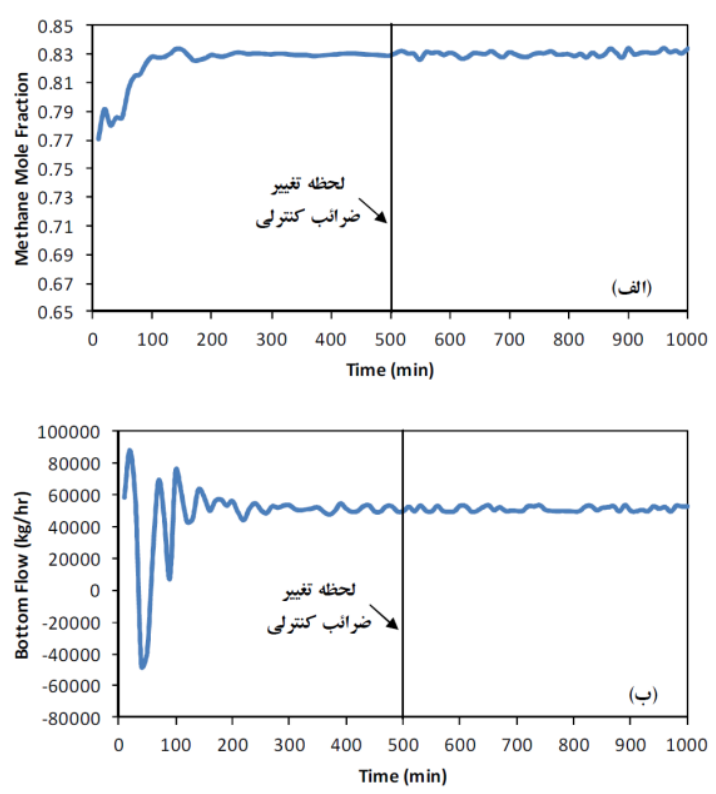

شكل r. متغيرهاى مهم فرايندى در حالت خوراك طر احى: الف) كسر مولى متان

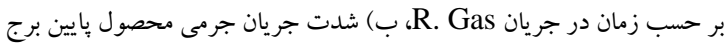

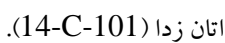

PIC-) در شكل F-الف عملكرد كنترل كننده فشار خروجى اكسيندر 100) نشان داده شده است. با توجه به شكل، متغير خروجى يعنى فشار در

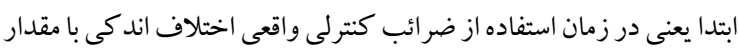

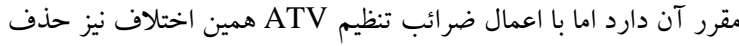
مى شود. از سوى ديخر اين متغير در تمام مدت شبيه سازى بدون نوسان أنمان

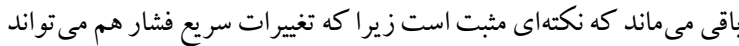

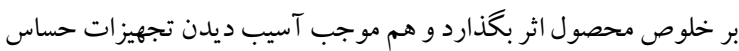
مثل كميرسورها و يمبها شود. لازم به ذكر است كه شير كنترل مربوطه نيز تغييرات جندانى از خود نشان نمى دهد كه از نظر كاهش استهلاكك در اين ابزار حائز اهميت است. بنابراين در مجموع مى توان كفت كه اين كنترل كننده عملكرد خوبى در حفظ نقطه يايا دارد. PIC-) در شكل F-ب عملكرد كنترل كننده فشار بالاى برج اتان زدان

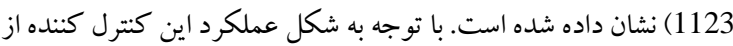
نظر نوسان نسبت به كنترل كننده PIC-100 بدتر اما از نظر افت كنترل بهتر

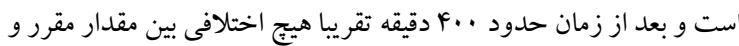
متغير تحت كنترل ديده نمى شود. اما آنجه كه در اين شكل بارزتر است،

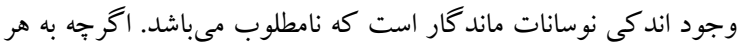
شكل، تنظيم ATV حداقل به اندازه ضرايب عملياتى عملكرد مطلوبى
توجهى مى گيرد، بررسى مىشود. در مسئله اخير كه در واقع حذف

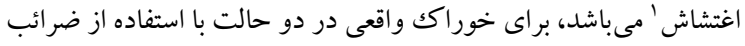

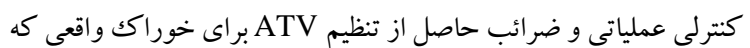
در قسمت اول حاصل شده با تغيير تركيب خوراكك در دقيقه .. مه، عملكرد سيستم مورد بررسى قرار مى گيرد.

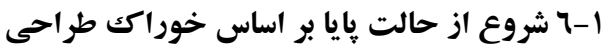

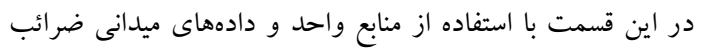
كنترل كنندهها تعيين شده و براى ميزان خوراك طراحى به ميزان IF./FV

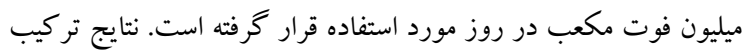

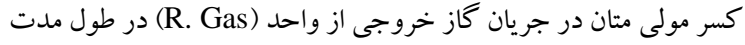

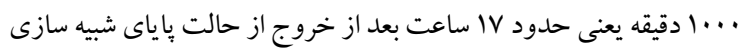
و ورود به حالت شبيه سازى ديناميكى در شكل ب-الف نشان داده شده

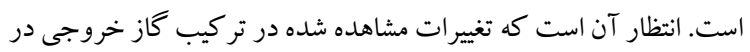
اين شر ايط ناجيز باشد. با توجه به شكل بـالف در ابتداى شروع شبيه سازى

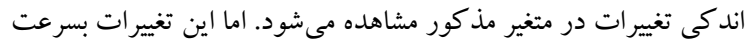

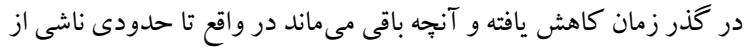

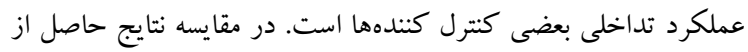

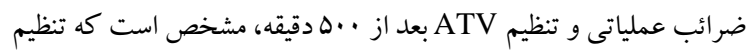
ATV لازم به يادآورى است كه اين متغير تحت عمكلرد مستقيم هيج كنترل كنندهاى نمىباشد.

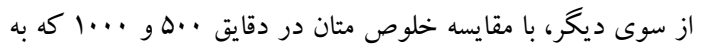

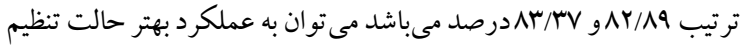

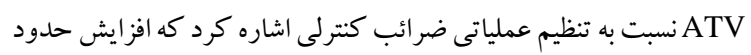

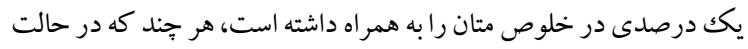
تنظيم ATV اندكى نوسانات بيشترى را شاهد بوديم. در ضمن مقدمار

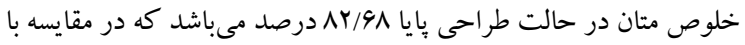

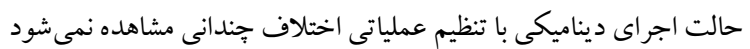

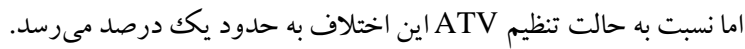
شدت جريان پيايين برج اتان زدا (جريان Bottom) كه به واحد

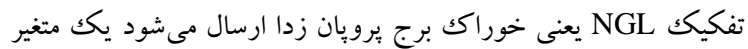

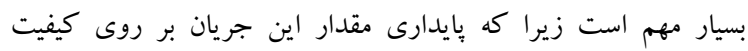

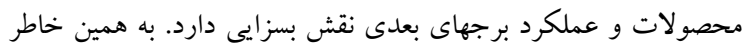

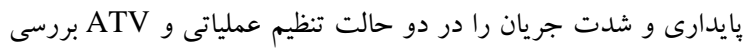

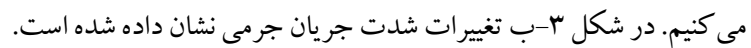
همانطور كه مشخص است اين جريان در ابتدا و با استفاده از ضرائب

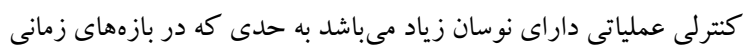

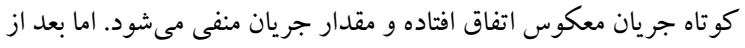

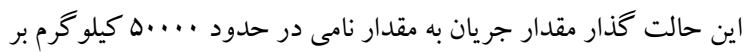
ساعت مىرسد كه مقدارى نسبتا مطلوب است جرا كه با ميزان حالت 
شرايط طراحى انتخاب شدهاند و نه براساس آنجه در شرايط واقعى در

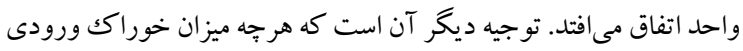

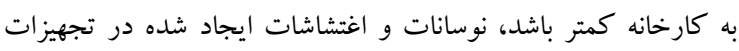
كنترلى بر روى خلوص محصول تاثير بيشترى خو اهند داشت. اما آنجه از

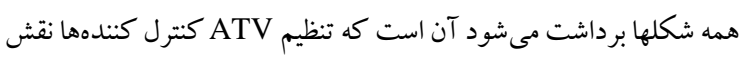
مشخصى در كاهش نوسانات و افت كنترل دارد.

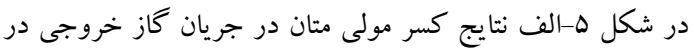

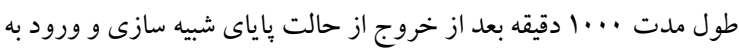

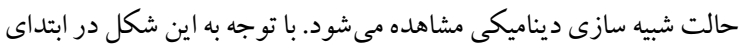

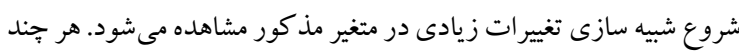

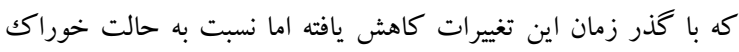

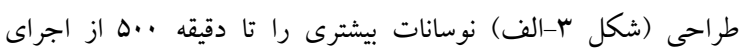
ديناميكى فرايند شاهد هستيم كه مى تواند ناشى از انتخاب بارامترهاى

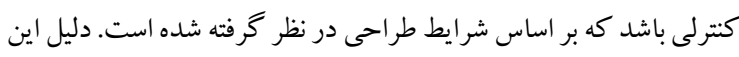

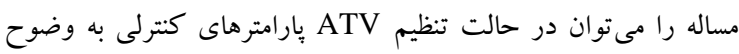

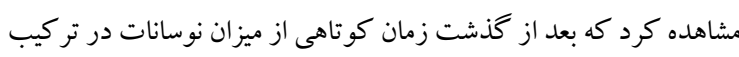

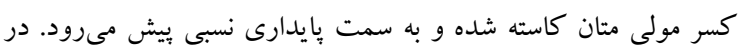

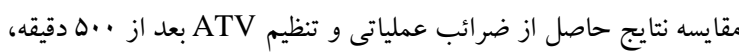

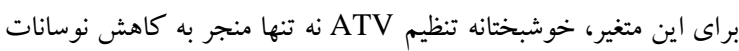

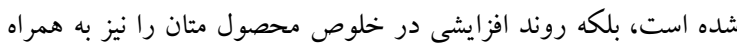

داشته است.
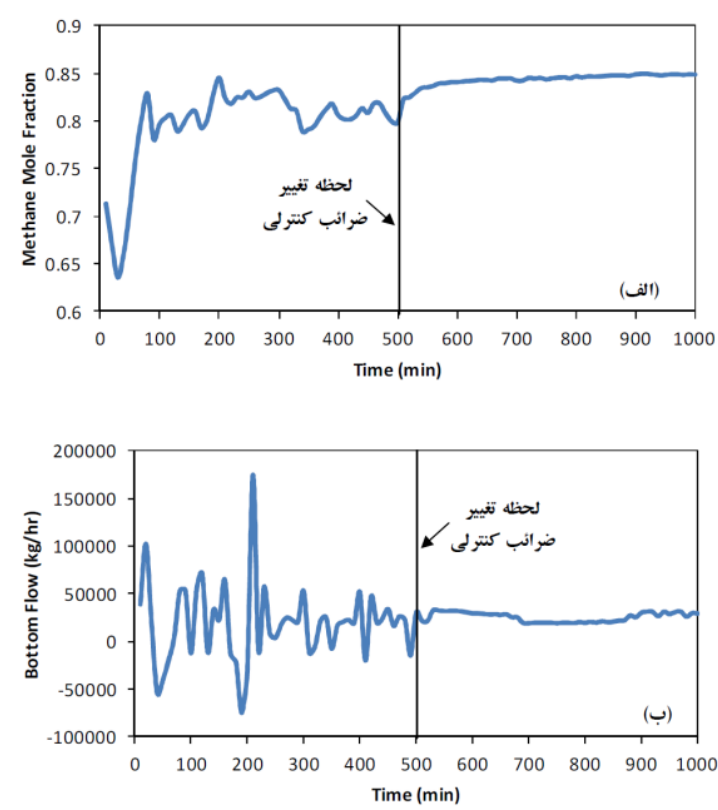

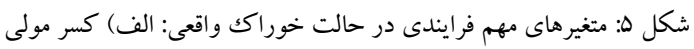

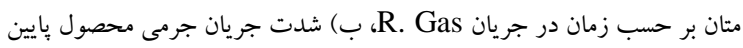

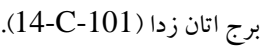

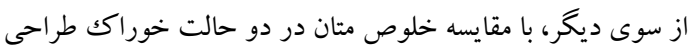

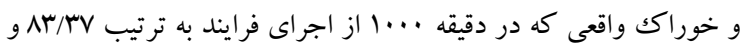
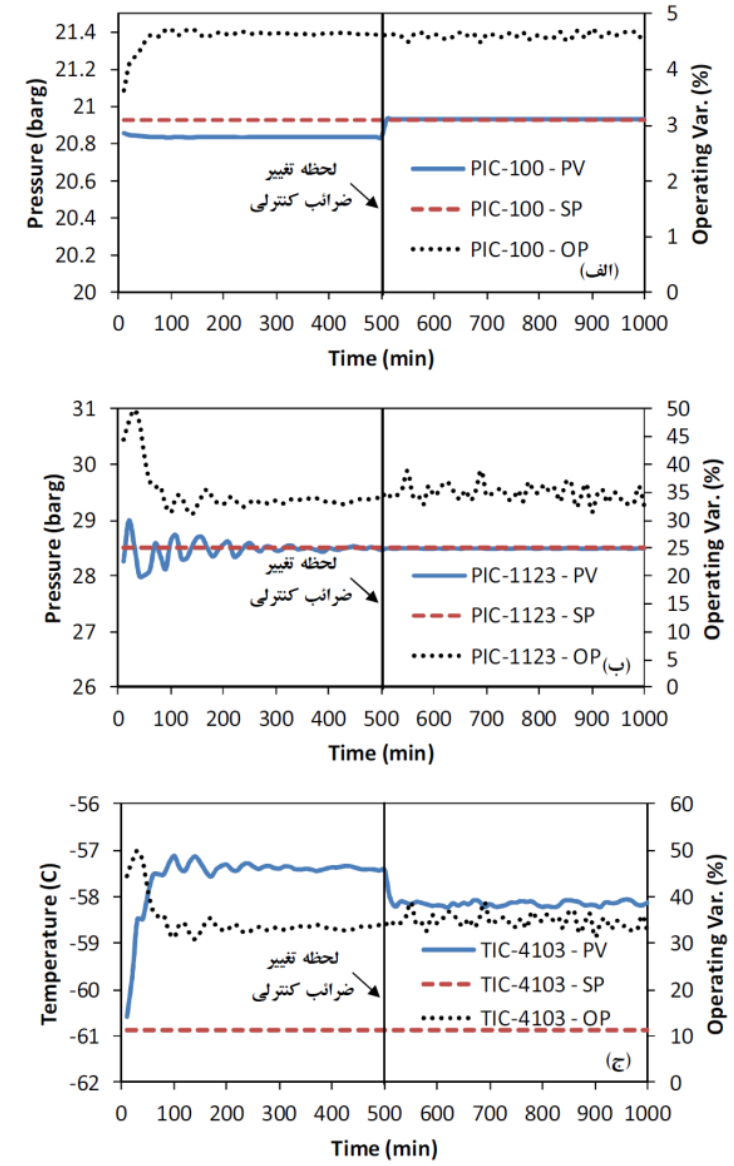

شكل ^: تغيير ات مرتبط با كنترل كندههاى اصلى در حالت خوراك طراحى:

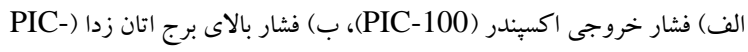

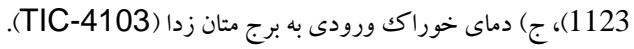

به طور مشابه در شكل ץ+

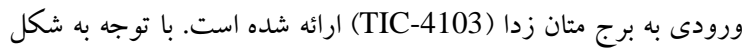

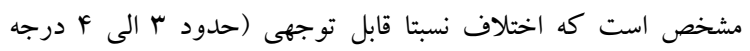

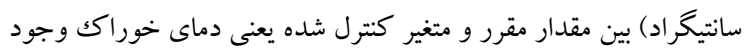

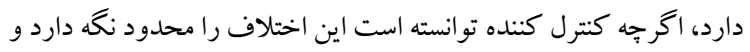
از سوى ديخر نوسانات متغير خروجى را نيز در طول زمان كاهش دهن دهد.

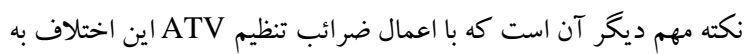
ميزان قابل توجهى يعنى در حدود ا درجه سانتيخر اد كاهش مى يابد كه إنه البته اين به بهاى افزايش نوسانى است كه به شير كنترل تحميل شده است.

\section{r-7 شروع از حالت پايا بر اساس خوراك واقعى}

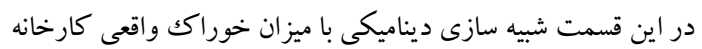
FD/VV) ميليون فوت مكعب بر روز با استفاده از ضر ائب كنترل كنندهها

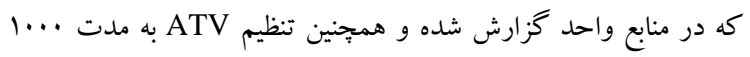
دقيقه اجرا شده است. تغييرات متغيرهاى اساسى و كنترل كنندهاى اصلى

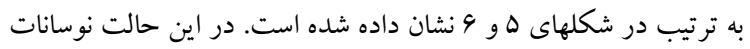

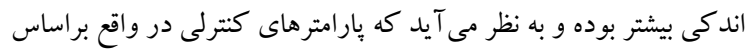


بيزّن ملىى، حميد باكوئى كتريمى
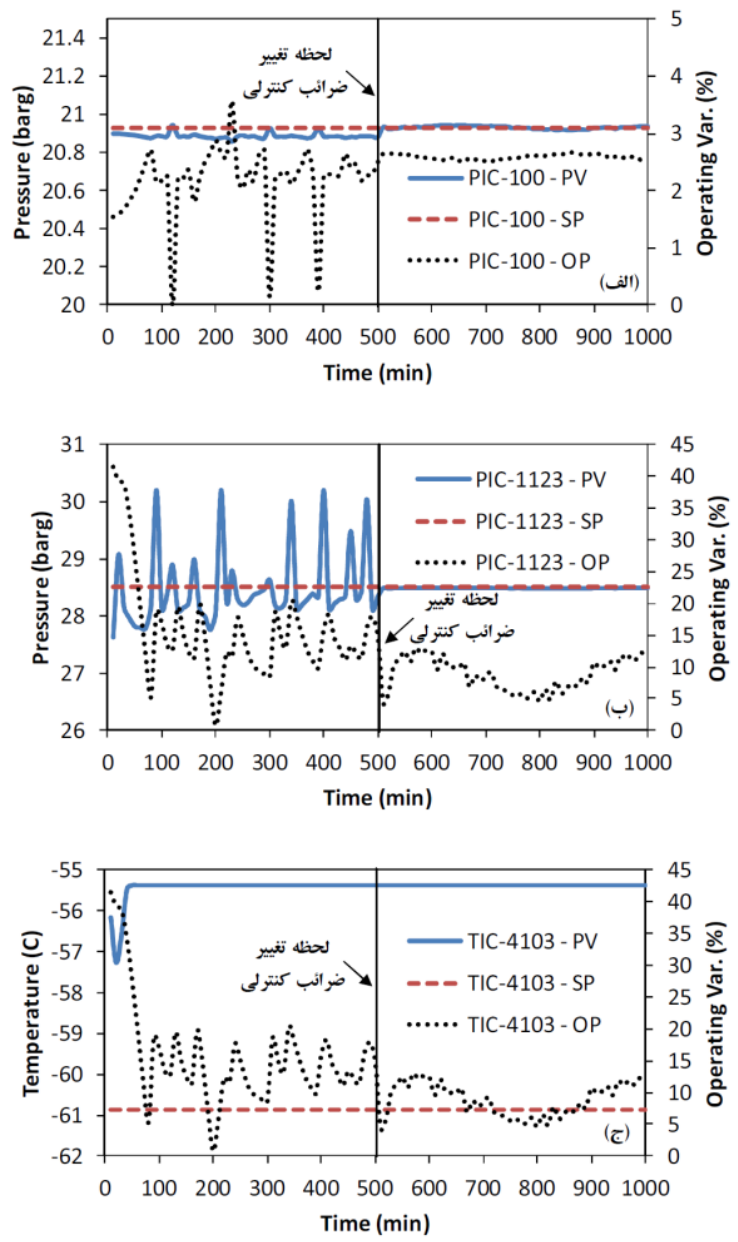

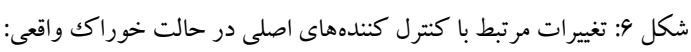

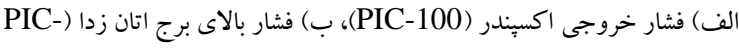

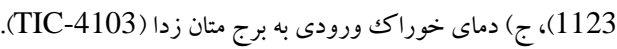

در شكل 9-ج عملكرد كنترل كننده دماى خور اكك ورودى به برج

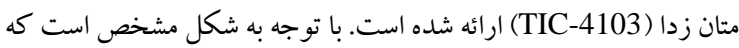

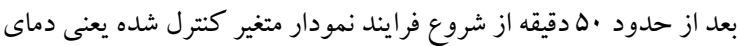
خوراكك جه در حالت استفاده از ضرائب كنترلى عملياتى و جه در حرد حالت

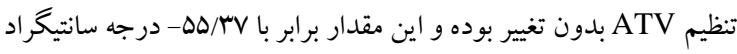

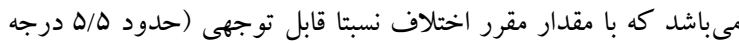

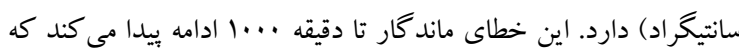

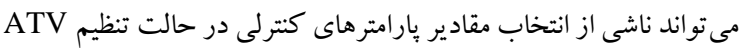

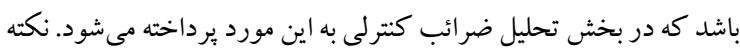

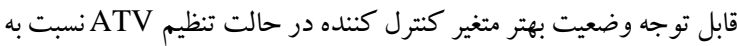
حالت عملياتى مىباشد كه نوسانات كمترى را در آن شاهد هستيم.

\section{r-7 تغيير تر كيب خوراك و حذف اغتشاش}

تغيير تر كيب خور اكك ورودى به واحدهاى فر ايندى مى تو اند به عنوان يكك حوفي

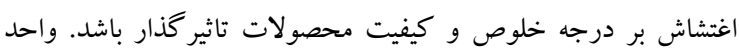

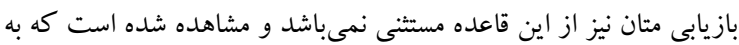
دليل برخى تغييرات در واحدهاى بالا دستى از جمله در سرويس قرار
NF/VA

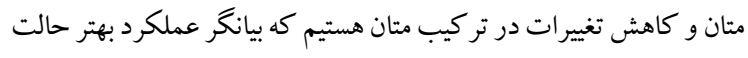

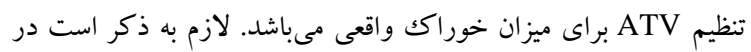

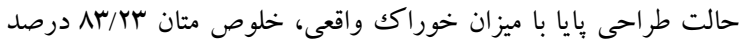

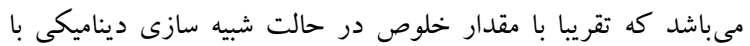
ضر ايب كنترلى عملياتى برابرى مى كند. همانطور كه قبلا اشاره شد شدت جريان پِيين برج اتان زدا كه به واحد تفكيك NGL ارسال مىشود بسيار مهم بوده و در اين قسمت نيز بايدارى شدت جريان را در دو حالت تنظيم عملياتى و

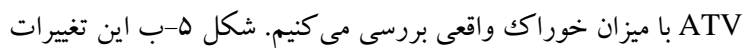

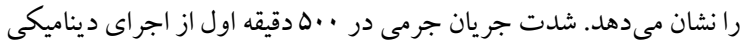
فرايند كه با استفاده از ضرائب كنترلى عملياتى شبيه سازى شده با بانوسانات بسيار زيادى همراه است به حدى كه در بازههاى زمانى كوتاه جريان

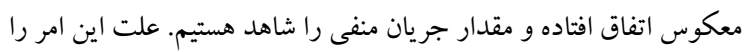

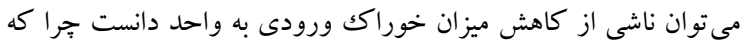

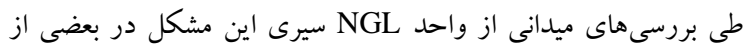

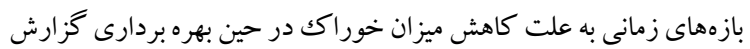
شده است. در ادامه اجراى فرايند و از دقيقه ل.ه با اعمال ضر ائب تنظيم ATV

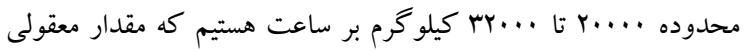

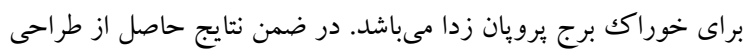

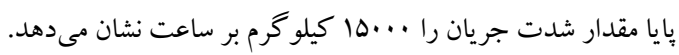

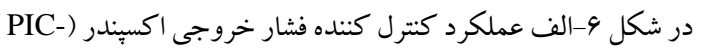
100) نشان داده شده است. با توجه به شكل متغير كنترل شده يعنى فشار

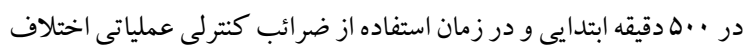

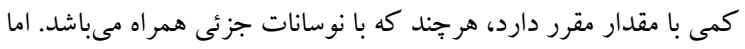
نكته قابل توجه در اين قسمت مربوط به شير كنترل مى باشد كه تغييرات

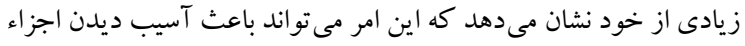

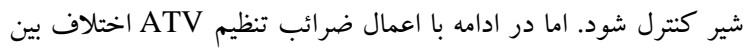
متغير فشار با مقدار مقرر تقريبا حذف شده و از ميزان نوسانات شير كنترل نيز كاسته مىشود.

به طور مشابه در شكل 9-ب عملكرد كنترل كننده فشار برج اتان زدا

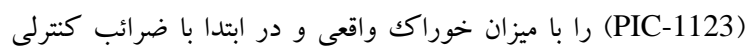
عملياتى نشان مىدهد. با توجه به شكل، عملكرد اين كنترل كننده از نظر

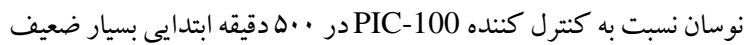

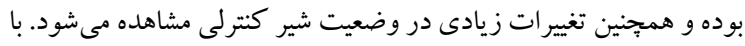

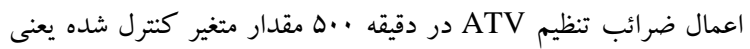

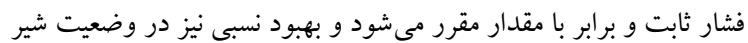
كنترل حاصل مى گردد. 
R. جدول \&: تركيب درصد محصول خروجى از بالاى برج متان زدا (جريان

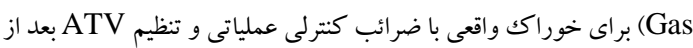

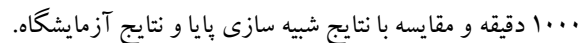

\begin{tabular}{|c|c|c|c|c|}
\hline تنظيم ضاضي كنترلى & باضر ائب كنترلى & آزتايجًاه & شازي & اجزاء \\
\hline$\Lambda q / F Y$ & MN/VF & $\Lambda 9 / \Delta \Delta$ & $1 N / 90$ & $\mathrm{C}_{1}$ \\
\hline $9 / 11$ & $9 / 49$ & $\mathrm{~V} / \mathrm{A}$. & $9 / 19$ & $\mathrm{C}_{2}$ \\
\hline $1 / Y F$ & $1 / \Delta r$ & $r / 19$ & $1 / 19$ & $\mathrm{C}_{3}$ \\
\hline$\cdot / \cdot v$ & .1 .9 & .119 &.$/ . \Delta$ & $\mathrm{i}-\mathrm{C}_{4}$ \\
\hline .1 .4 & $\cdot / \cdot 1$ &.$/ 10$ & $\cdot / \cdot$ & $n-C_{4}$ \\
\hline$\%$ & $\%$ & .119 & $\cdot / \cdot$ & $\mathrm{i}-\mathrm{C}_{5}$ \\
\hline$\%$ & $\%$ & $\cdot / \cdot r$ & $\cdot / \cdot$ & $\mathrm{n}-\mathrm{C}_{5}$ \\
\hline$\%$ & $\%$ & $\cdot / \cdot$ & $\cdot / \cdot$ & $\mathrm{n}-\mathrm{C}_{6}$ \\
\hline$\%$ & $\%$ & $\%$ & $\cdot / \cdot$ & $\mathrm{n}-\mathrm{C}_{7}$ \\
\hline$\%$ & $\%$ & $\%$ & $\cdot / \cdot$ & $\mathrm{n}-\mathrm{C}_{8}$ \\
\hline$\%$ & $\%$ & $\%$ & $\cdot / \cdot$ & $\mathrm{n}-\mathrm{C}_{9}$ \\
\hline$\%$ &.$/ \cdot$ & $\%$ & $\cdot / \cdot$ & $\mathrm{n}-\mathrm{C}_{10}$ \\
\hline $.19 \mathrm{~V}$ & $.19 \mathrm{~V}$ &.$/ 4$. &.$/ 94$ & $\mathrm{~N}_{2}$ \\
\hline$r / r V$ & $r / r q$ & $r / F$. & $r / \Delta Q$ & $\mathrm{CO}_{2}$ \\
\hline$\cdot / \cdot$ & $\%$ & $\cdot / \cdot$ & $\%$ & $\mathrm{H}_{2} \mathrm{~S}$ \\
\hline$\%$ & $\%$ & $\%$ & $\%$ & $\mathrm{H}_{2} \mathrm{O}$ \\
\hline
\end{tabular}

PIC-) شكل ^-الف عملكرد كنترل كننده فشار خروجى اكسيندر

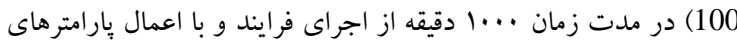
كنترلى از روى منابع واحد را نشان مى دهد. در . .ه دقيقه اول شاهد نوسان جزئى در متغير خروجى يعنى فشار هستيم، همجنين اختلاف بين مقدار

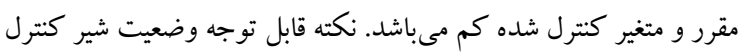
مىباشد كه در .0ه دقيقه ابتدايى تغييرات زيادى به همر اه دارد اما با تغيير تر كيب خوراكك وضعيت شير كنترل نرمال و درصد باز بودن آن تقريبا

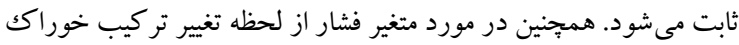

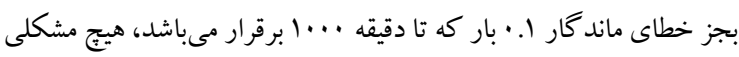

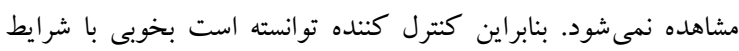
خور راك واقعى تطابق داشته باشد.
كرفتن جاه توليدى جديد و يا از سرويس خارج شدن برخى جاههاى

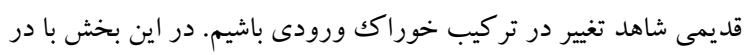

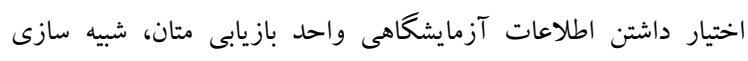

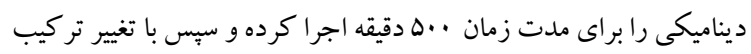

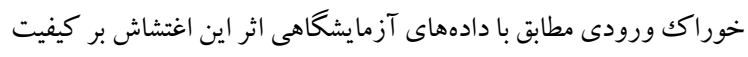

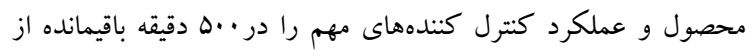
اجراى ديناميكى فرايند بررسى مى كنيم. اين بررسى يكبار با استفاده از

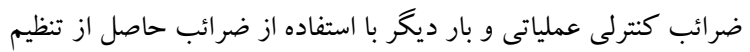

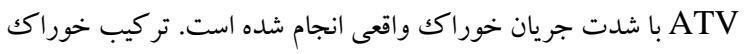
اصلى در حالت طراحى (از منابع واحد) و خوراكك واقعى (نتايج آزمايشگاهى) در جدول ب ارائه شده است.

جدول r: تر كيب درصد مولى خوراكك طراحى و خوراكك واقعى (نتايج آزمايشگاه).

\begin{tabular}{|c|c|c|c|c|c|}
\hline واقعى & طراحى & اجزاء & واقعى & طراحى & اجزاء \\
\hline.$/ .9$ & . & $\mathrm{n}-\mathrm{C}_{7}$ & $\Lambda r / r$ & $V Y / 49$ & $\mathrm{C}_{1}$ \\
\hline.$/ \cdot 1$ & .110 & $\mathrm{n}-\mathrm{C}_{8}$ & $\mathrm{~V} / \mathrm{V}$. & $11 / \mathrm{VA}$ & $\mathrm{C}_{2}$ \\
\hline$\cdot / \cdot$ & $\cdot / \cdot v$ & $\mathrm{n}-\mathrm{C}_{9}$ & $r / 9 \Delta$ & $\mathrm{V} / \mathrm{rq}^{\mathrm{q}}$ & $\mathrm{C}_{3}$ \\
\hline$\cdot / \cdot$ &.$/ \cdot r$ & $\mathrm{n}-\mathrm{C}_{10}$ & $\cdot \mid \mathrm{Al}$ & $1 / r \Delta$ & i- $-C_{4}$ \\
\hline$\cdot / 9$ & $\cdot / 09$ & $\mathrm{~N}_{2}$ & $1 / r$. & $r / 19$ & $\mathrm{n}-\mathrm{C}_{4}$ \\
\hline$r / \kappa$. & $r / 4 F$ & $\mathrm{CO}_{2}$ & $\cdot / / 4$ & $\cdot / \Delta \Lambda$ & $\mathrm{i}-\mathrm{C}_{5}$ \\
\hline$\cdot / \cdot$ & 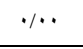 & $\mathrm{H}_{2} \mathrm{~S}$ & $\cdot / \pi \Delta$ & $\cdot / \Delta \Lambda$ & $\mathrm{n}-\mathrm{C}_{5}$ \\
\hline$\cdot / \cdot$ & $\%$ & $\mathrm{H}_{2} \mathrm{O}$ & $\cdot / r$. & $\cdot / \cdot r$ & $\mathrm{n}-\mathrm{C}_{6}$ \\
\hline
\end{tabular}

با توجه به شكل V-الف در دقيقه . .ه با تغيير تركيب جريان خوراك

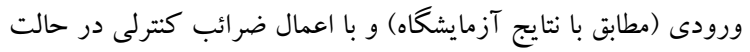

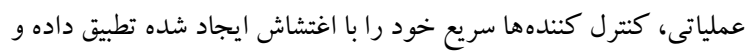

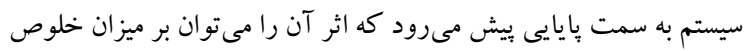

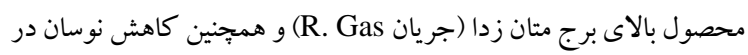
تركيب محصول شاهد بود. درصد مولى متان در خوراكك ورودى مطابق با بان

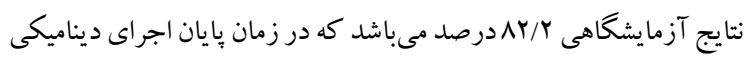

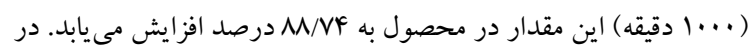

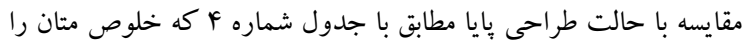

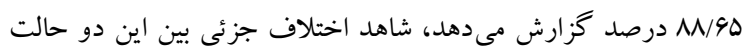
هستيم. شكل V-ب تغييرات شدت جريان بايين برج اتان زدا (Bottom) را

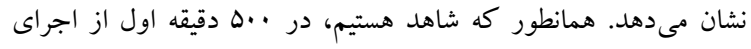

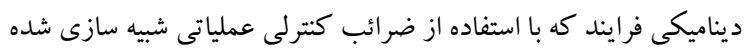

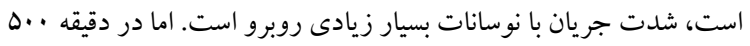

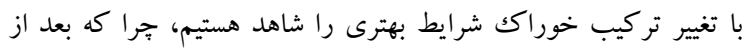

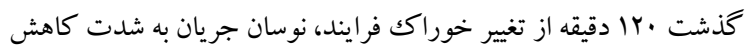

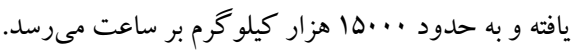


به طور مشابه شكل ^-ب عملكرد كنترل كننده فشار بالاى برج اتان

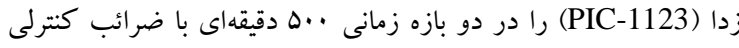

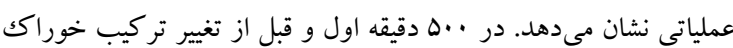
شاهد نوسان بسيار زيادى در متغير كنترل شده يعنى فشار و همجنين

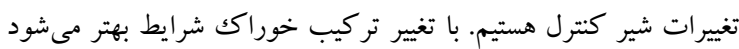

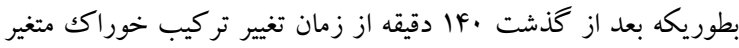
كنترل شده برابر با مقدار مقرر شده و خطا تقريبا به صفر مىرسد همجئنين تغييرات جزئى در وضعيت شير كنترل را شاهد هستيم. در شكل ^-ج عملكرد كنترل كننده دماى خور اكك ورودى به به برج

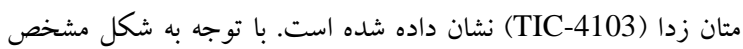

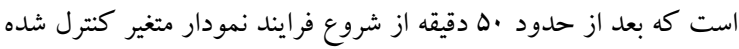

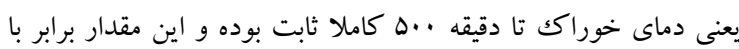
ته حه/TV

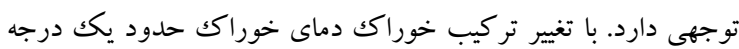

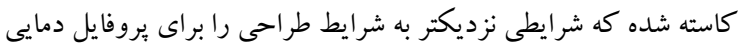
برج ايجاد مى كند. همجِين شاهد تغييرات كمترى در وضعيت شير كنترل

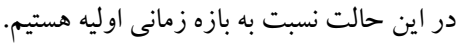

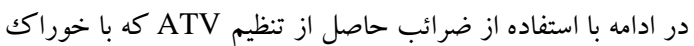

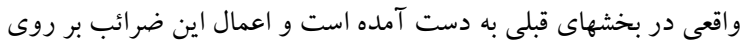

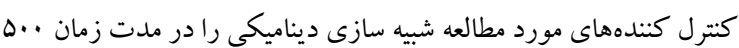
دقيقه با تر كيب خوراك اصلى شروع كرده و همانند مرحله قبل با تغيير

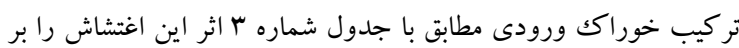
كيفيت محصول و عملكرد كنترل كنندهاى مهم در بـ به دقيقه باقيمانده

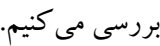
در شكل q-الف تغييرات درصد مولى متان در جريان R. Gas در دو بازه زمانى نشان داده شده است. در ..ه دقيقه اول بعد از اعمال ضر ائب

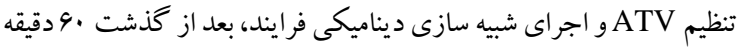

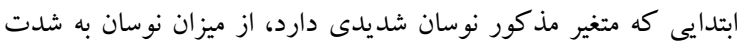
كاسته شده و شرايط بايدارى در تغييرات درصد مولى متان شاهد هستيم. همجنين نسبت به شرايط استفاده شده از ضرائب عملياتى براى كنترل كنندها در حالت خوراك واقعى (شكل V-الف) كه نوسان بيشتر و ميانگين r د درصدى خلوص متان را مشاهده كرده بوديم، در اين حالت

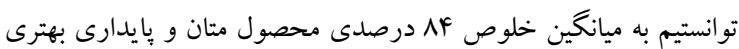

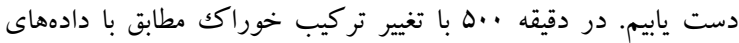

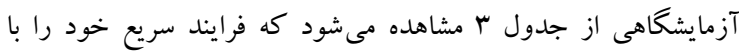

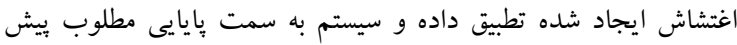

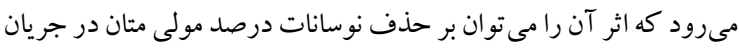

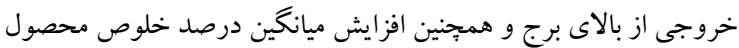

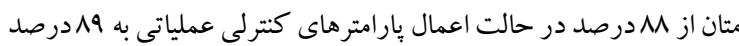
درحالت اعمال بارامترهاى كنترلى ATV شاهد بود. نتايج حاصل نشان از مزيت تنظيم ATV نرم افزار هايسيس در بهبود عملكرد يارامترهاى كنترلى تئي
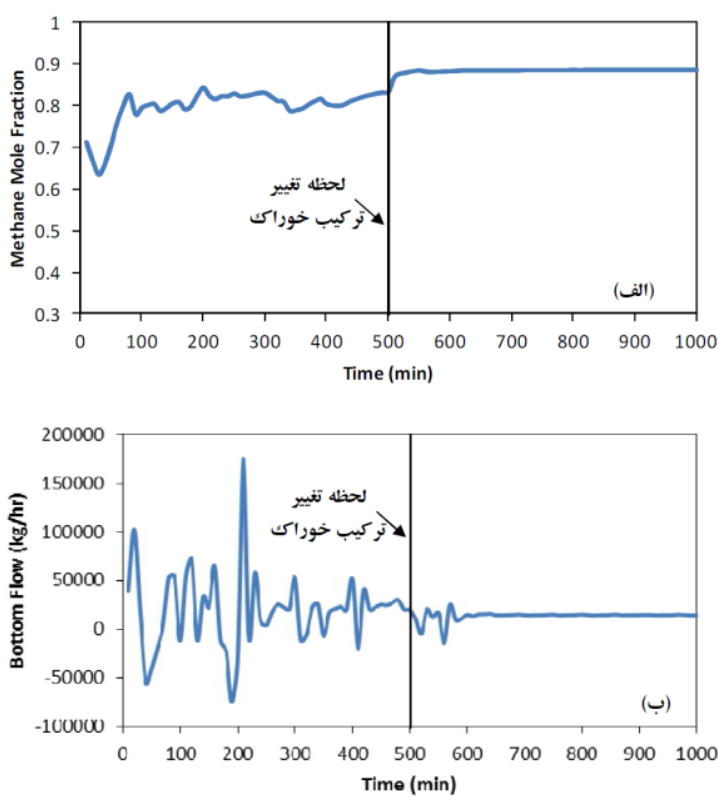

شكل V: الف) كسر مولى متان بر حسب زمان در جريان R. Gas و ب) شدت جريان جرمى محصول هايين برج اتان زدا (

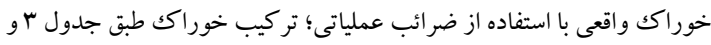
ه دقيقه بِ از شروع شبيه سازى تغيير كرده است.
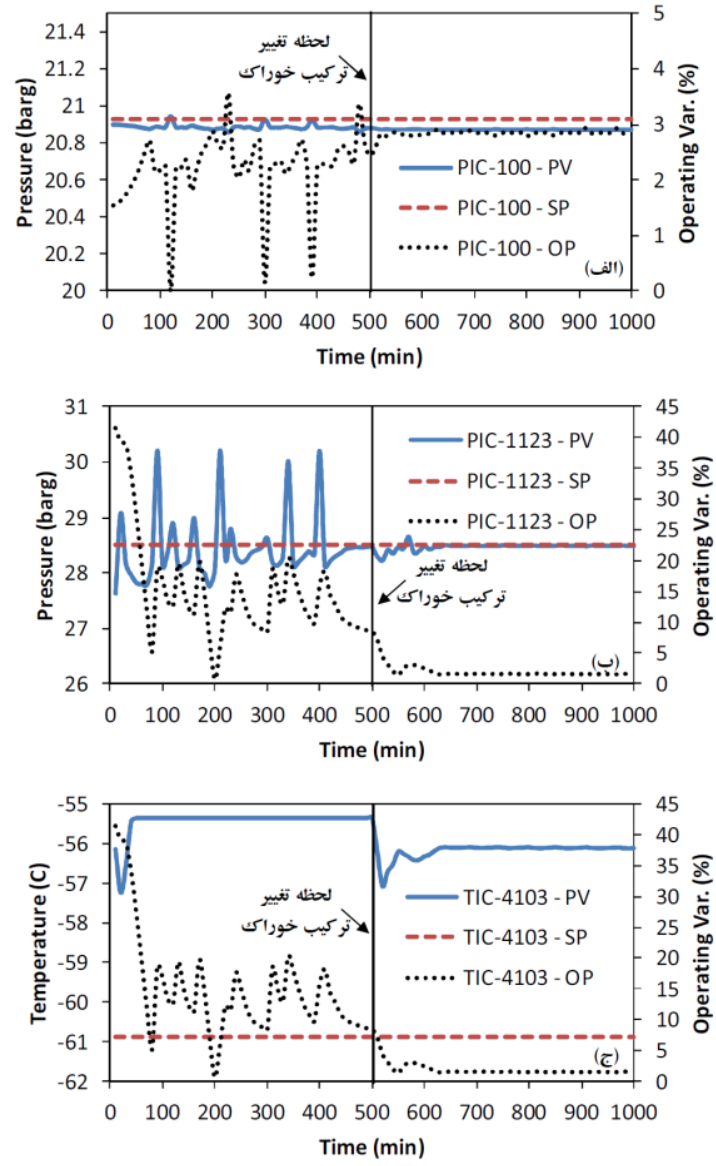

شكل من تغييرات مرتبط با كنترل كندههاى اصلى در شدت جريان خوراكى

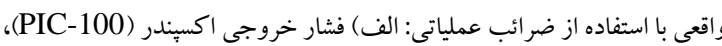

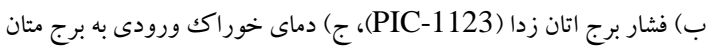
زدا (TIC-4103). 
AIC-) شكل • ا-الف عملكرد كنترل كننده فشار خروجى اكسبندر

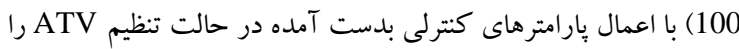

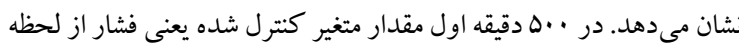
اجراى شبيه سازى ديناميكى تقريبا به مقدار مقرر خود مى دهرسد و نو نوسان

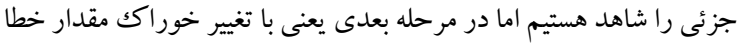

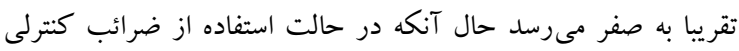
عملياتى (شكل ^-الف) با خطاى ماندكار در اين بازه زمانى مواجه بوديم. از مزيتهاى ديخر اين حالت وضعيت ملايمتر تغييرات شير كنترل در مقايسه با حالت قبلى مىباشد كه از آسيب به تجهيزات فرايندى جلو گيرى كرئ مرده و باعث مى شود تا شرايط برج بايدارتر باشد.

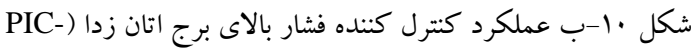

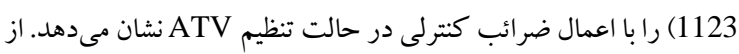

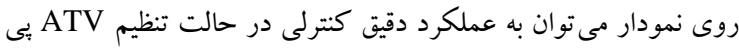

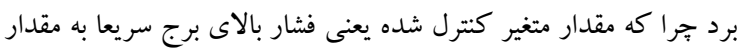

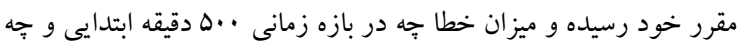

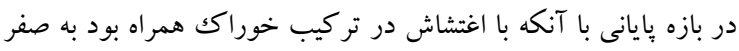

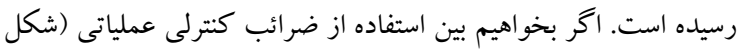
^-ب) و ضر ائب كنترلى تنظيم ATV (شكل • (1-ب) مقايسهاى در شرايط

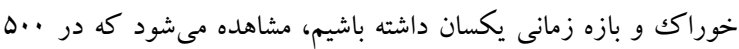
دقيقه ابتدايى در حالت تنظيم عملياتى با نوسان زيادى در متغير كنترل شده

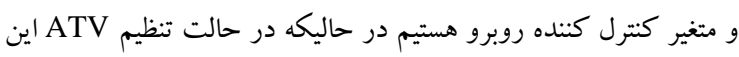

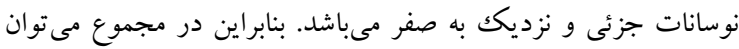

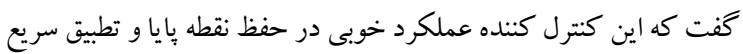
با شرايط در صورت اعمال اغتشاش را دارد.

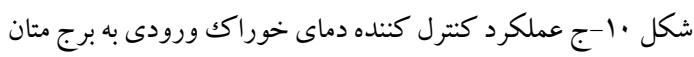
زدا (TIC-4103) را در حالتى كه از ضرائب كنترلى در حالت تنظيم ATV استفاده شده است، نشان مىدهد. با توجه به شكل مشخص است در

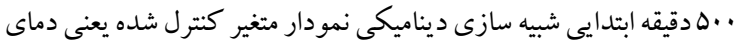

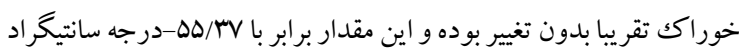

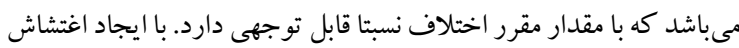
در تركيب خوراكك دماى خوراكك روند نزولى داشته و شاهد نوسانات

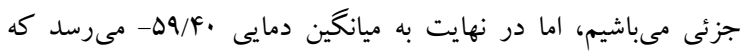

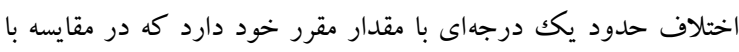

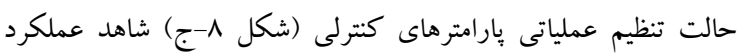
مطلوبترى مى باشيم كه به طبع بر خلوص محصول متان و شرايط مائ عملياتى برج متان زدا تاثير مثبت دارد.
مىباشد. جهت بررسى بهتر مى توان در جدول عانتايج حاصل از دادههاى آزمايشكاهى و دادههاى بدست آمده از شبيه سازى بِايا و همجِنين شبيه

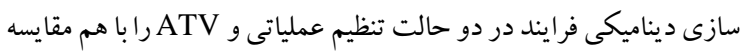

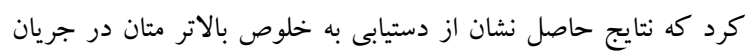
خروجى از بالاى برج متان زدا در حالت شبيه سازى ديناميكى با اعمال ضرايب تنظيم ATV نسبت به ديكر حالت هاى شبيه سازى ديناميكى و پايا

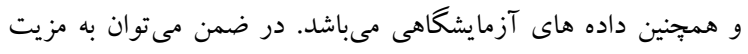

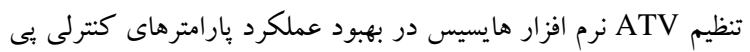

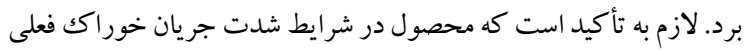

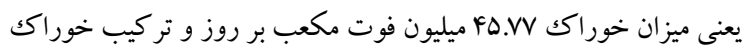
كزارش شده در جدول لم بدست آمده است.
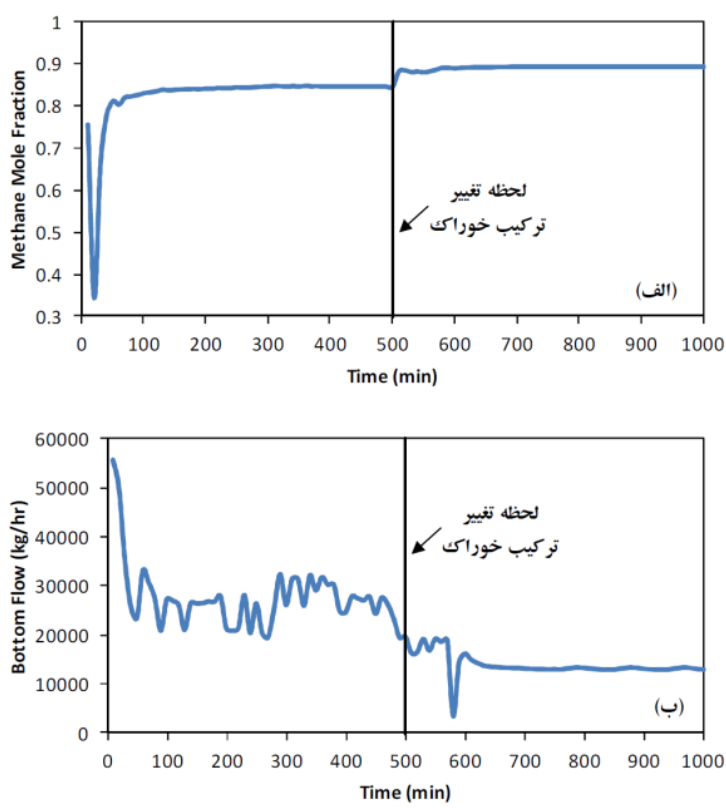

شكل ه: كسر مولى متان بر حسب زمان در جريان R. Gas و ب) شدت

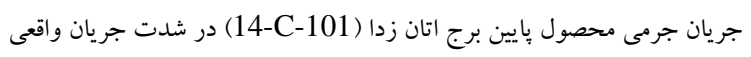

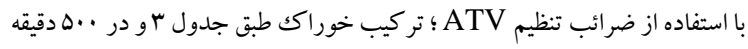
يس از شروع شبيه سازى تغيير كرده است.

شكل ه-ب تغييرات شدت جريان جرمى جريان بايين برج اتان زدا

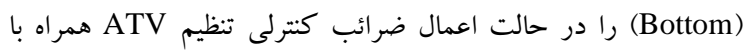

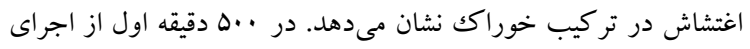

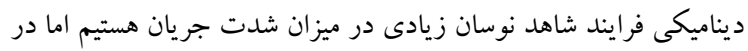

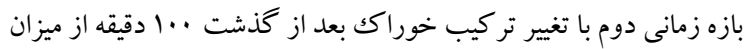

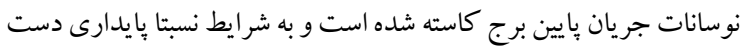

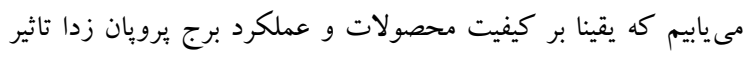

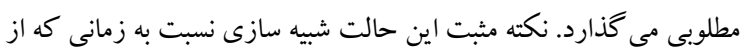

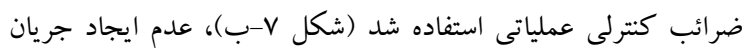
معكوس است كه نشان دهنده برترى تنظيم ATV پارامترهاى كنترلى مىباشد. 


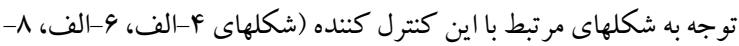

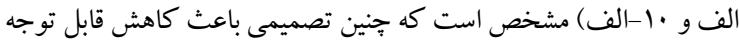

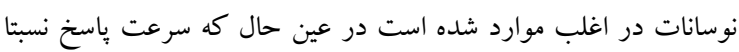
بالاست و افت كنترل هم ناجيز است. لازم به ذكر است اختلاف قابل

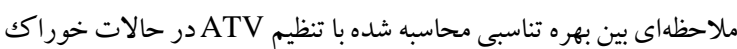
واقعى و خوراكك طر احى ديده مى شود كه مى تواند ناشى از تغيير قابل توجه

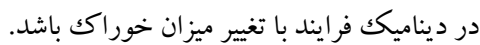

جدول ه: ضرائب كنترل كننده فشار خروجى اكسيندر (PIC-100).

\begin{tabular}{|c|c|c|c|}
\hline$T_{d}(\mathrm{~min})$ & $T_{i}(\min )$ & $K_{p}$ & ضرائب كنترلى \\
\hline . & - & 1 & عملياتى \\
\hline$r / \wedge r \times 10^{-r}$ & $1 / V Y \times 1 .^{-r}$ & $. / 1 . r$ & ATV - خوراكك واقعى \\
\hline $1 / V \wedge \times 1 .^{-r}$ & $N / r \times 1 \cdot^{-r}$ & . /FYA & - خوراكك طراحى ATV \\
\hline
\end{tabular}

\section{r-ع-1 كنترل كننده فشار بالاى برج اتان زدا (PIC-1123)}

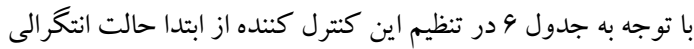

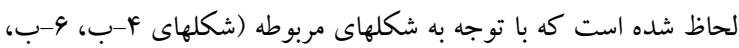
1-ب و • (-ب) مشخص است كه تنظيم عملياتى منجر به نوسان قابل توجه

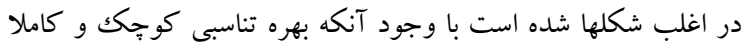

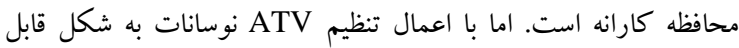

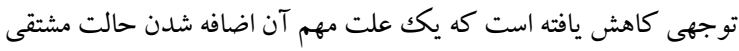

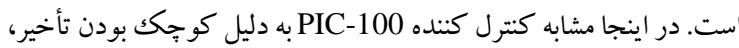

$$
\text { ثوابت انتخر الى و مشتقى كو جكك انتخاب شدهابند. }
$$

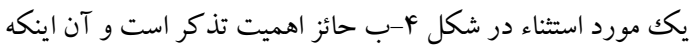
احتمالا به دليل بالا بودن حاصلضرب بهره در ثابت زمانى مشتقى نو سانات

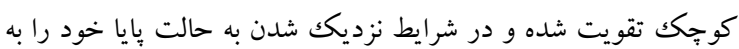

صورت نوسانات در شير كنترل نشان مىدهند كه نامطلوب است. جدول و: ضرائب كنترل كننده فشار بالاى برج اتان زدا (PIC-1123).

\begin{tabular}{|c|c|c|c|}
\hline$T_{d}(\min )$ & $T_{i}(\min )$ & $K_{p}$ & ضر ائب كنترلى \\
\hline . & $\cdot / v \Delta$ & $\cdot / r \Delta$ & عملياتى \\
\hline $1 / r r \times 1 \cdot{ }^{-r}$ & $\Delta / \mathcal{F}^{\prime} \times 1 \cdot^{-r}$ & $1 r / 9$ & - خوراكك واقعى - ATV \\
\hline$r / V V \times 1 \cdot \cdot^{-r}$ &.$/ 1 Y \Delta$ & $\mid q / 4$ & - خوراكك طراحى ATV \\
\hline
\end{tabular}

\section{r-ع-7 كنترل كننده دماى خوراكى ورودى به برج متان}

زدا (TIC-4103)

با توجه به جدول V مشخص است كه طر احان اصلى، كند بودن حلقه

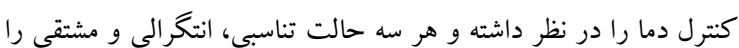
براى كنترل دماى خور اكك برج متان زدا مورد استفاده قرار دادهاند كه البته

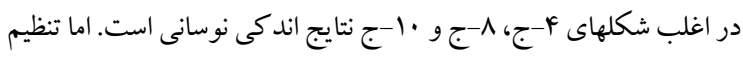
ATV

نوسانات ارائه دهد، در عين حال كه افت كنترل نيز كاهش يافته است.

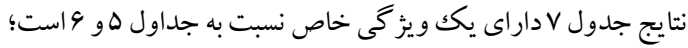

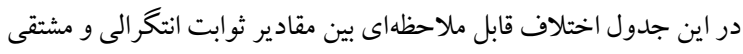

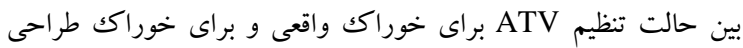
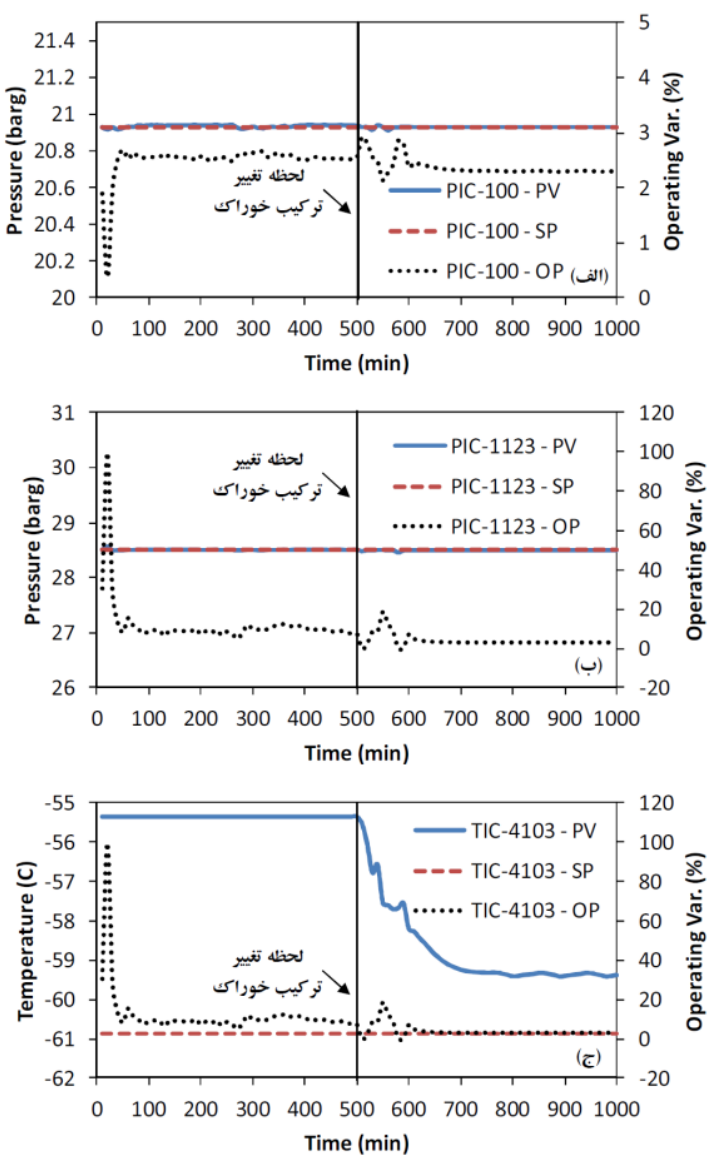

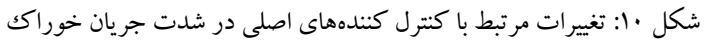

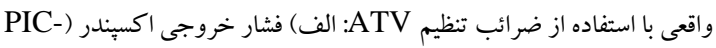

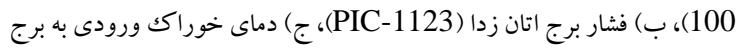
متان زدا (TIC-4103).

ع-7 مقايسه ضرائب كنترلى عملياتى و حاصل از تنظيم

در اين بخش به بررسى بارامترهاى كنترل كنندهاى اصلى كه در

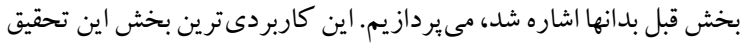

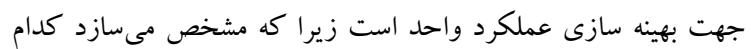

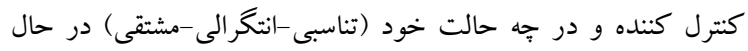
حاضر اختلاف قابل ملاحظهاى با شرايط مطلوب دارد. در اينجا لازم

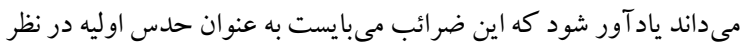

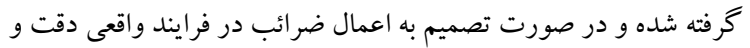

احتياط بيشترى به عمل آورد.

1-ع-ح كنترل كننده فشار خروجى اكسيندر (PIC-100) ضرائب كنترلى اين كنترل كننده در جدول ها ارائه شدهاند. كنترل

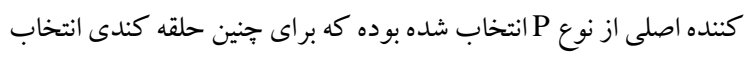

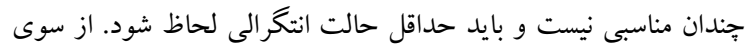

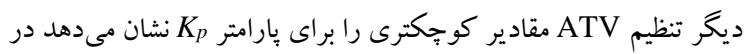

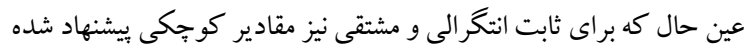

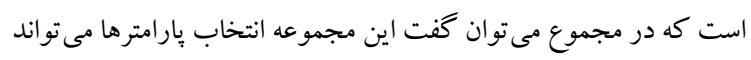

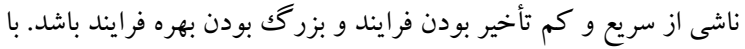


اكر جه در اينجا سعى شد عملكرد كليه حلقههاى كنترلى بهبود يابد،

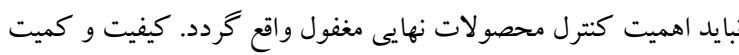
محصولات در حال حاضر طبق دستورالعملهاى راهبرى واحد تنظيم

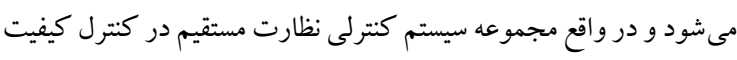
محصول ندارد، در عين حال كه در اين روش تضمينى هم بر بهينه بودن

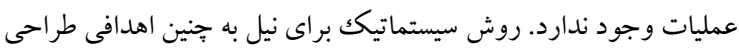
سيستم كنترل در قالب مسائل كنترل بهينه است كه از جمله معروفترين

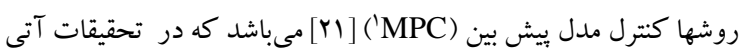

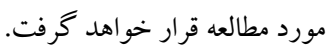

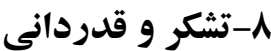

بدين وسيله از واحد بهره بردارى و واحد آزمايشگاه كارخانه NGL سيرى به خاطر در اختيار قرار دادن اسناد و مداركك بروزّه و همجيجنين دادههاى آزمايشگاهى تشكر و قدردانى مى شود.

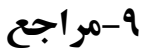

يولادى برج، ب.، جهار لنك، ش.، ثقه الاسلامى، ن.، "شبيه

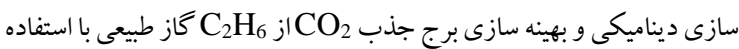

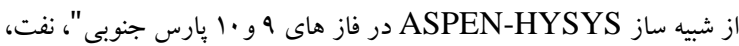

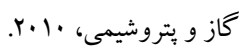

[2] Luyben, W. L., "Dynamic simulation of multi-effect evaporators", Chemical Engineering and Processing - Process Intensification, vol. 131, pp. 106-115, 2018.

[3] Khodadoost, M., Sadeghi, J., "Dynamic Simulation of Distillation Sequences in Dew Pointing Unit of South Pars Gas Refinery", Journal of chemical and petroleum engineering, vol. 45 , no. 2 , pp. 109-116, 2011.

[F] تو كلى دستجردى، ف.، صادقى، ج.، حسن يور، س.، "شبيه سازى

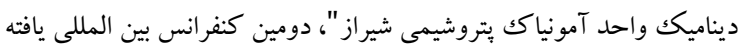

هاى نوين بزوهشى در شيمى و مهندسى شيمى، هوسا.

يبمانى، ع.، ملكى، ب.، حسين زاده، م.، صادقى، ج.، "شييه سازى

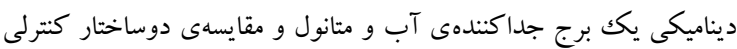

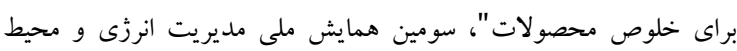

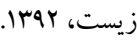

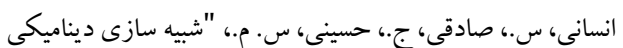

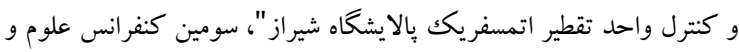

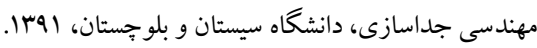

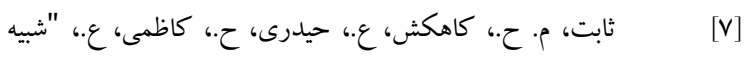

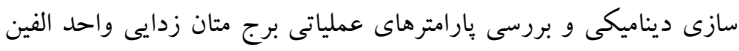

مشاهده مىشود كه نشان دهنده اثر مهم ميزان خوراكك بر ديناميك اين بخش از فرايند مىباشد.

جدول V: ضر ائب كنترل كننده دماى خور اكك ورودى به برج متان زدا (4IC .4103

\begin{tabular}{|c|c|c|c|}
\hline$T_{d}(\min )$ & $T_{i}(\min )$ & $K_{p}$ & ضر ائب كنترلى \\
\hline$\cdot / T \Delta$ & $r$ & $\cdot / \wedge$ & عملياتى \\
\hline.$/ .1$ & - & 1 & ATV - خوراكك واقعى \\
\hline$r / \cdot 1$ & $1 r / \Delta$ & $1 / \cdot 1$ & - خوراك طراحى ATV \\
\hline
\end{tabular}

\section{Y-بحث و نتيجه كيرى}

از آنجا كه تاكنون تحليل جامعى بر رفتار ديناميكى واحد بازيابى متان

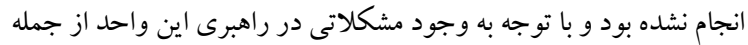

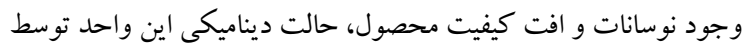

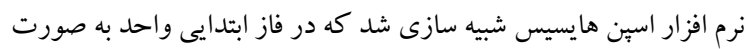

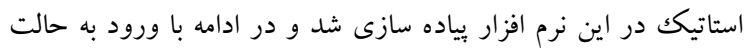
ديناميك و افزودن حلقه هاى كنترلى شبيه سازى ديناميكى تكميل گرديد ديد.

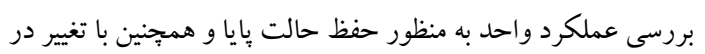

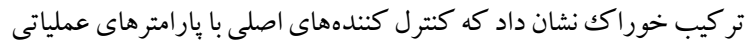

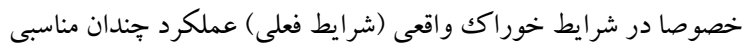

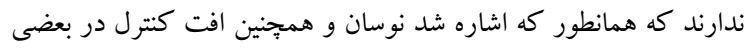

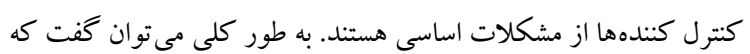

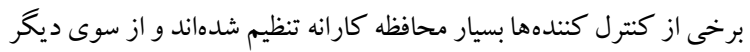
از حالات انتخر الى و مشتقى كنترل كننده PID به طور كار كار آمد استفاده

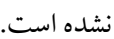
با اجراى سناريوهاى مورد نظر، نحوه تغييرات متغيرهاى اصلى و

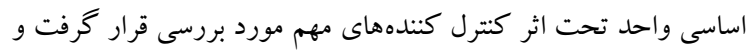
مشخص شد كه نوسانات مزاحم يكى از مشكلات اصلى اغلب حلقههاى

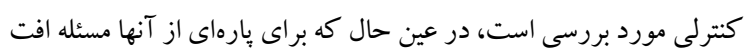

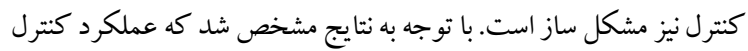

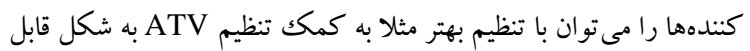
توجهى بهبود بخشيد كه در قالب كاهش نوسانات و كاهش افت كنترل

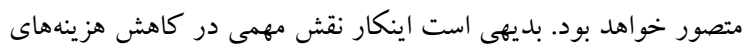

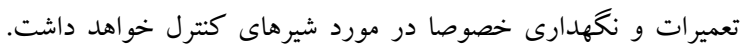
كيفيت محصول نيز از ديد ميزان متان در اغلب موارد بهبود يافته و نوسانات

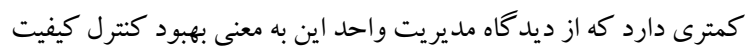

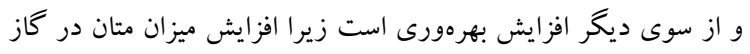

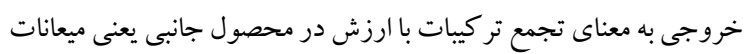

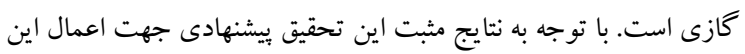

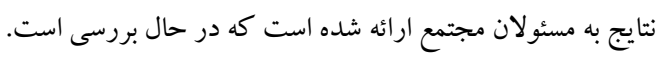




$$
\begin{aligned}
& \text { يتروشيمى جم به منظور افزايش ظرفيت"، دومين كنفرانس ملى و بين المللى }
\end{aligned}
$$

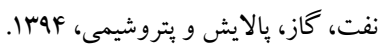

$$
\begin{aligned}
& \text { جلالى، ع.، شفيعى، م.، مرادى، م.، "شبيه سازى و بهينه سازى }
\end{aligned}
$$

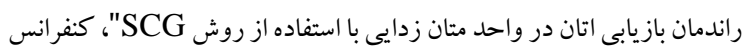

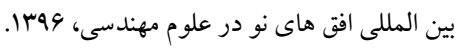

[9] Jibril, K. L., Al-Humaizi, A. I., Idriss, A. A., Ibrahi, A. A., "Simulation of turbo-expander processes for recovering of natural gas liquids from natural gas", Saudi ARAMCO Journal of Technology, Fall, pp. 9-14, 2005.

[10] Najibi, S. H., Darabi, H., Kamali, M. J., "A Feasibility Study of the Technologies for Deep Ethane Recovery from the Gases Produced in One of the Iran Southern Fields", Iranian Journal of Oil \& Gas Science and Technology, vol. 1, no. 1, pp. 13-24, 2012.

[11] Aspen Technology, "Dynamic Modeling", 2005.

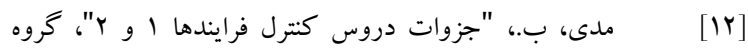

$$
\begin{aligned}
& \text { مهندسى شيمى، دانشخاه صنعتى همدان، هوبا. }
\end{aligned}
$$

[13] Stephanopoulos, G., "Chemical process control: an introduction to theory and practice", Prentice-Hall international series in the physical and chemical engineering sciences, 1984.

[14] Friman, M., Waller, K. V., "Autotuning of Multiloop Control Systems", Industrial \& Engineering Chemistry Research, vol. 33, no. 7, pp. 1708-1717, 1994.

[15] Ogunnaike, B. A., Ray, W. H., "Process dynamics, modeling, and control", Topics in chemical engineering, New York, Oxford University Press, 1994.

[16] Al-Malah, K.I.M., Aspen Plus® Dynamics, in Aspen Plus ${ }^{\circledR}$, K.I.M. Al-Malah, Editor, John Wiley \& Sons, Inc., 2016.

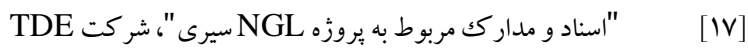

$$
\begin{aligned}
& \text { كانادا و شر كت طراحى و مهندسى انرزى (EIED). }
\end{aligned}
$$

[18] Mehrpooya, M., Gharagheizi, F., Vatani, A., "An Optimization of Capital and Operating Alternatives in a NGL Recovery Unit ,"Chemical Engineering \& Technology, vol. 29, no. 12, pp. 1469-1480, 2006.

[19] Lin, H. M., "Peng-Robinson equation of state for vapor-liquid equilibrium calculations for carbon dioxide + hydrocarbon mixtures", Fluid Phase Equilibria, vol.16, no. 2, pp. 151-169, 1984.

[20] Glitsch, "Ballast Tray Design Manual, Bulletin 4900, $3^{\text {rd }}$ Ed.", Glitsch, The Separations Company, 1980.

[21] Medi, B., Monzure-Khoda, K., Amanullah, M., 2015, "Experimental Implementation of Optimal Control of an Improved Single-Column Chromatographic Process for the Separation of Enantiomers", Industrial \& Engineering Chemistry Research, vol. 54, no. 25, 6527-6539. 